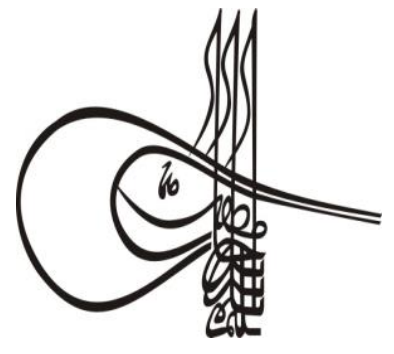

\begin{abstract}
Research Article / Araştırma Makalesi
Article Info/Makale Bilgisi
\end{abstract}

\section{Cutkigh Studieg \\ Social Sciences}

Volume 14 Issue 6, 2019, p. 2925-2953

DOI: 10.29228/TurkishStudies. 37822

ISSN: 2667-5617

Skopje/MACEDONIA-Ankara/TURKEY

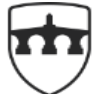

INTERNATIONAL

BALKAN

UNIVERSITY

EXCELLENCE FOR THE FUTURE IBU.EDU.MK

Received/Geliş: 25.09.2019

(18.10.2019)-Referee 2 (26.11.2019)

This article was checked by turnitin.

\title{
MINYYTÜR SANATINDA ZÜMRÜDÜ ANKA KUŞU VE BİR TASARIM ÖRNEĞİ
}

\author{
Elif BAYRAK KAYA* - Bilgehan KAYA**
}

\begin{abstract}
öz
Efsaneler, destanlar ve masallar toplumların geçmişten geleceğe sesleniş biçimidir. Bize; içinden çıtığı toplumların, gelenek ve görenekleri, inanç sistemi ve yaşam biçimi hakkında sağlam veriler verir. Bunun yanı sıra efsaneler, destanlar ve masallar doğup misafir oldukları dillerde dönemin coğrafya yapısı ve iklim özellikleri hakkında da bilgiler sunmaktadır.

Efsane, destan ve masallarda bahsi geçen kahramanlar kimi zaman insan kimi zaman mitolojik yaratıklar olmuștur. Bahsi geçen bu yaratıkların bir kısmı gerçekte var olmuş olabileceği gibi, belki de var olanlar üzerine mübalağa yapılarak veya tamamen hayal gücünün birer ürünü şeklinde ortaya çıkmış olabilirler.

Zümrüdü Anka (Simurg) denilince, büyük çoğunluğun bir ya da birkaç masala, hayatına dokunmuş olması muhtemeldir. Zümrüdü Anka-Simurg'un hafızalarda, anlatıldığı hikâyedeki rolüne göre, bazen iyilik timsali, cesur, yardımsever ve bir kahraman olarak bazen ise huzur bozan, kötülük ve dehşet saçan canavar bir kuş olarak kalmıștır. Minyatür kompozisyonlarda bu efsanevi mitolojik kuş 'un birçok yorumu vardır. Bu yorumlar Zümrüdü Anka 'nın iyi veya kötü karakter taşımasıyla doğru orantılıdır. Yapılan yorumların geneli, birbirine benzerlik göstermekle birlikte, istisnai örneklerde mevcuttur.
\end{abstract}

Bu makalede, maslarımızı süsleyen Zümrüdü Anka (Simurg) kuşunun anlamı, taşıdığ1 sembolik değerler ve Zümrüdü AnkaSimurg'un konu edildiği bazı minyatürler ve çizim incelenmiş olup ayrıca

Dr.Isparta Uygulama Bilimler Üniversitesi, E-posta: elifbayrakkayaart@ gmail.com

Öğr. Gör. Süleyman Demirel Üniversitesi, E-posta: bilgehankayagsf@gmail.com 
minyatür kompozisyon biçiminde bir tasarımı çizilerek Zümrüdü Anka yorumu, uygulamalı bir biçimde sergilenmiştir.

Anahtar Kelimeler: Simurg, Zümrüdü Anka Kuşu, Minyatür Sanat1, Efsane, Tasarım

\title{
PHOENIX IN MINIATURES AND A DESIGN SAMPLE
}

\begin{abstract}
The legends, sagas, and tales are forms of address from past to future for societies. They give us solid information regarding traditions, customs, belief systems as well as ways of living in societies where they originated from. The tales, sagas, and legends also reflect the geographical and climatic features of the era through the languages they were created at.

The heroes or heroines mentioned in legends, sagas, and tales usually hold human features while they sometimes could be mythological figures or creatures. Some of those creatures mentioned could have existed in reality while they might have also been built upon various creatures through some exaggeration or could completely be works of human fantasy.

When the word "Phoenix" (Simurg) is mentioned, it is possible that the vast majority have touched one or more tales, their lives. According to the role of Anka-Simurg in memories, the emerald remains a monument of goodness, courageous, benevolent and sometimes as a hero, and sometimes as a monster that disturbs peace, and spreads evil and horror. There are many interpretations of this mythical mythological bird in miniature compositions. These comments are directly proportional to the good or bad character of Emerald Phoenix. Although the general comments are similar, they are present in exceptional examples

In this article, the meaning of Phoenix (Simurg), the symbolic values that it holds and various miniatures and designs on which Phoenix was depicted have been explored while a design of Phoenix has been drawn in a form of composition.
\end{abstract}

\section{STRUCTURED ABSTRACT}

Either by exciting or scaring people, the supernatural, so to say unusual, creatures in legends, sagas and fairy tales have always been appealing to people. Being commonly the elements of oral literature, such legendary unusual creatures have been influenced by a number of cultural features like life styles, beliefs, as well as value judgements of the people and societies on their journey from one generation to another as cultural assets while they are still under the influence of such factors even at the present time. The reflection of these mythological creatures in writings and drawings is, for certain, significant for world literature history. The societies have interpreted, named or put these legendary creatures in a form in their own ways or they have created their own 
heroes or enemies though they have no idea as to when and where these legendary creatures originated.

The physical and spiritual characteristics, the relationships with people, the location where it used to settle and the form of creation of the Simurgh (The Phoenix), one of these mythological creatures, have been explored in this study. The study has also investigated in which other cultures it existed, its generic name, its character traits, the special powers and skills that it had. The Simurgh, that often appears in the literary works of Asian and Eastern cultures, have a great number of appearances in visual arts like miniature, drawing and graphs as well. The interpretations regarding the Simurgh (The Phoenix) have been analysed by investigating various visual representations of the Simurgh (The Phoenix) and the similarities and discrepancies in these interpretations have been identified.

The Simurgh embodies the features of plenty other bird species in terms of ability and appearance. Thus, we clearly observe the attempt in Turkish Islamic Art interpretations to create a unique form of Simurgh or Phoenix that emerges by combination of plenty elements within itself instead of representing it as it is in the nature. This attempt of differentiation or creating a new form called fully-stylized or half-stylized literally stems from the fear that the forms created by the God cannot be copied in their exact forms, which led to the emergence of unique Turkish Islamic Arts. The physical appearance of the Simurgh, made up of appearances of a number of other bird species, brought about a lot of different interpretations and representations along with its superior abilities as a supernatural character while it is quite significant that the artists who brought the Simurgh characters into being identified it through cultural values of the societies, beliefs being in the first place, in which they lived.

This magnificent bird called by different names like the Phoenix/Simurgh, Garuda, Tugrul, Kara-kuş (Black bird), Grifon and Saena with its supernatural powers is depicted as a guardian spreading wellbeing and healing in some legends while in others it appears as a monster spreading terror and death. The miniatures illustrating the theme and found in the inscriptions of legends are invaluable evidences that help us view the Simurgh from the viewpoint of the public and the artist at the times the legend was being narrated. The descriptions of the Simurgh found in the scripts make us set our sails in a dream world while the Simurgh wallowing in colours by capturing the lines in the miniature drawings offers us a visual feast that evokes astonishment and admiration. Some of the miniature works that take the Simurgh and its actions as their theme have been investigated and a brand-new Simurgh interpretation (Black bird) has been presented to the public's taste. 


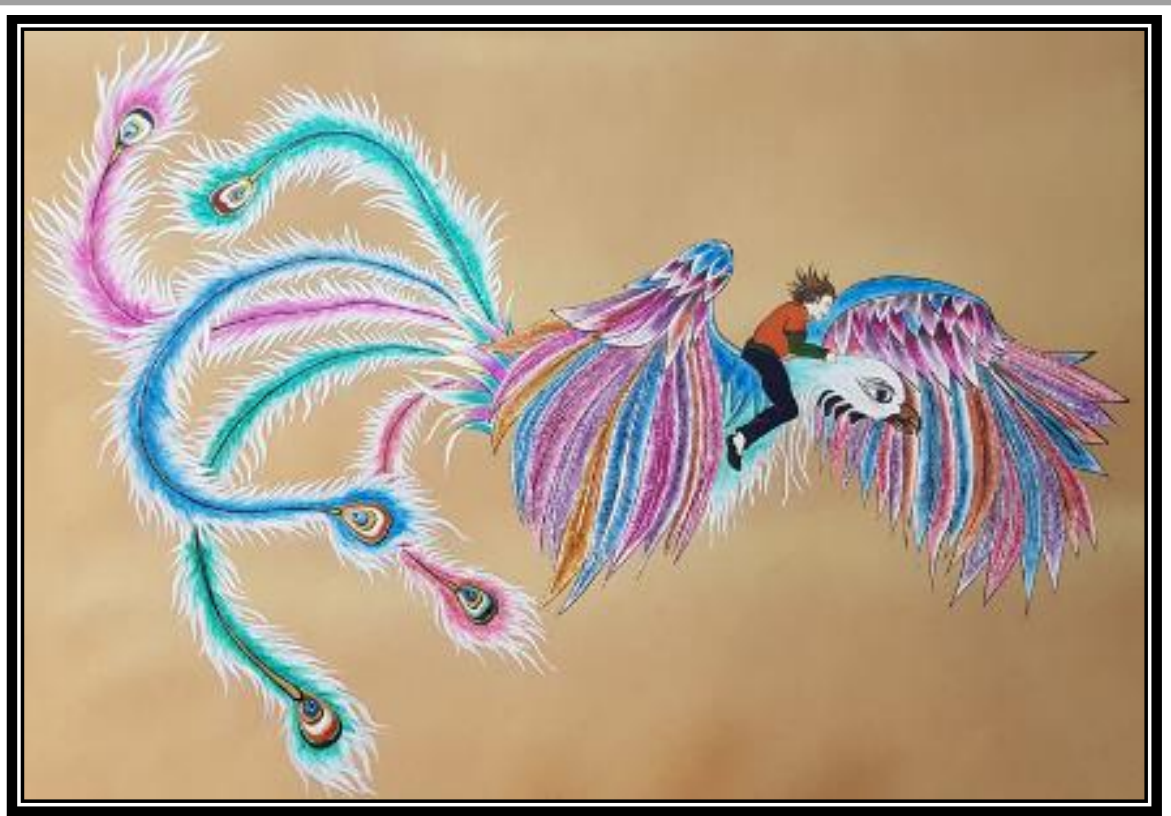

Image 1: Miniature representation of the Phoenix/Simurgh (Bayrak Kaya, E.2019).

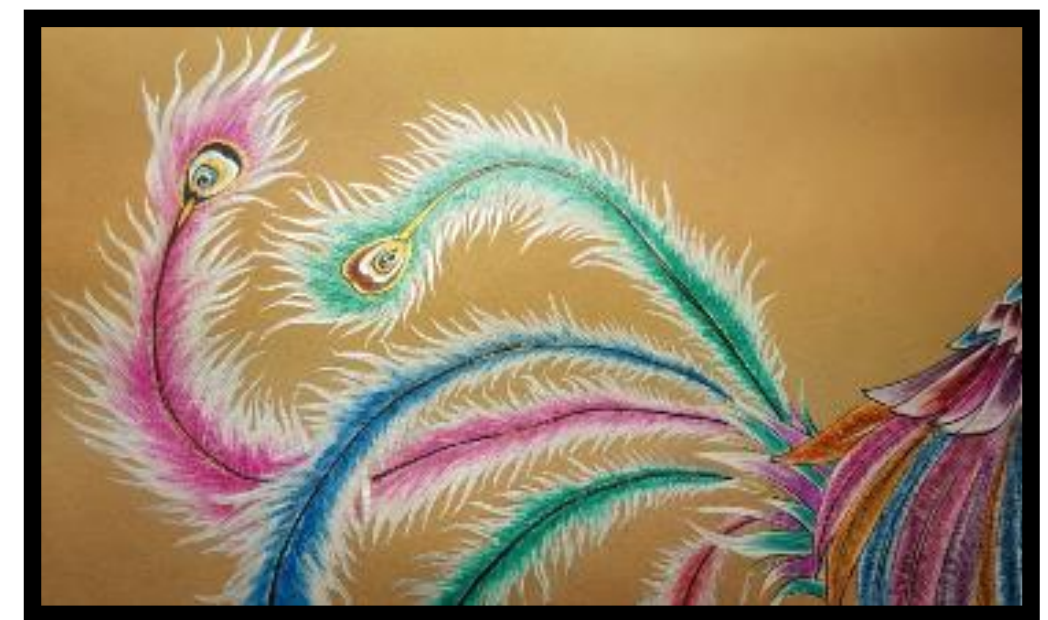

Image 2: A scene from miniature representation of the Phoenix/Simurgh (Bayrak Kaya, E.2019).

The new form of the Simurgh (the Phoenix) created as a result of all these studies and analyses depicts the bird as helpful, human-loving and solid. The unusual description of the head of the Simurgh (the Phoenix) unlike in the typical the Simurgh representations stems from the effort to add the bird a milder perspective and an aesthetical value.

There are a great number of legends, sagas, fairy tales and local stories as well as miniatures, drawings and images with the theme of the Simurgh (the Phoenix) that have not been mentioned in this study. The legends involving the Simurgh (the Phoenix) will be the scope of a further study along with detailed interpretations and analyses.

Keywords: Simurg, Phoenix, Miniatures, Legend, Design 


\section{Giriş}

Kitap resmi diye de bilinen Minyatür, ilk örneklerini orta Asya Uygur döneminde görülmektedir. Minyatürün duvar bezekligi olarak bilinen en erken örnekleri, minyatür desen ve kompozisyon bilgisi hakkında bize ışık tutmaktadır. Zamanla yazma kitaplar arasına giren minyatür burada yazma kitabın konusu ve ait olduğu sayfadaki bilgiler doğrultusunda bize bilgi vererek görsel bir anlatım sunar. Metni açıklayıcı bu resimler, zamanla yazma kitaplardan özgü tek başına levhalar olarak gelişim serüvenlerini sürdürmüşlerdir. Günümüz minyatürleri daha çok bu biçimdeki örneklerle karşımıza çıkmaktadır.

Minyatür sanatında hayali, pek çok doğa ve canlı türlerine de rastlanmaktadır. Bunlardan biriside Zümrüdü Anka kuşudur. Minyatür sanatında Zümrüdü Anka Kuşunun oldukça çok işlendiği görülmektedir. Sevilerek çizilen Anka kuşu, gerek yalnız gerekse kompozisyon içerisinde sıkça karşılaşmamı, Anka kuşuna yüklenen anlamlardan olsa gerektir. Bereketi, talihi, gücü, sabrı, adaleti, merhameti, cesareti, vb. pek çok anlamı temsil eder, Anka kuşu.

\section{Zümrüdü Anka/Sîmurg}

Simurgun kelime anlamı İran mitolojisinden gelmiştir. Kelime anlamı, otuz kuştur. Otuz ayrı kuşun özelliğini taşıdığına inanılır. Simurg devlet kuşu olarak ta bilinir. (S. Alsan ,2017:110)

Bahaeddin Ögel "Büyük hocamız Prof. Abdulkadir İnan, bu konuda çok kısa; fakat derin bir giriş yapmıştır diyerek şöyle devam etmiştir; Hint mitolojisindeki Garuda ile, İran'daki Simurg veya Zümrüd kuşlarının, Türkler arasına girmiş olduklarından hiçbir kuşku yoktur. Ancak Proto- Türk geleneklerinde, Tugrul gibi, Garudaya benzer büyük bir mitolojik kuşun bulunduğunu... Kuzey Türk destanlarında zaman, zaman, Garuda veya Zümrüd-Ankanın yerini "Kara-kuş", yani Türklerin kartalı alır." der. (Ögel, 2014:693)

Türklerin Budist ve Manihaist sanata intibakıyla Garuda ve Simurg gibi efsanevi kuşlarla ilişkisi meydana gelmiştir diyen Yaşar Çoruhlu ekler "İslamiyetin Türkler arasında yayılması ile de Anka veya Zümrüdü Anka ile ilgili benzer tasavvur ve semboller daha öncekilere ilave olmuştur. ... bu nedenlerden ötürü Simurg ile alakalı görünen efsanavi vasfı olan kuşlardan biride Phoenixdir." (Çoruhlu, 2014:7)

İslamiyet'ten evvelki Türk sanatının erken devirlerinde sanat eserlerinde grifonlar sıkça tasvir edilen yaratıklar idi. ...İslamiyet'ten önce en önemli merkezlerden biri Altaylar olan Türk sanatının kartal başlı grifonları, daha sonra Anadolu'ya kadar gelecek, Simurg ve Phoenix ile ilgili tasavvurlarla karışacaktır. Kartal veya yırtıcı kuş (avcı kuş) başları ve gövdenin farklı olması Hint mitolojisindeki ve Budist mitolojisindeki efsanevi yaratık Garuda kuşuyla da ilişkilidir. (Çoruhlu, 2014:7-8)

Aynı zamanda İran mitolojisinde Gaokerana Agacının tepesindeki Saena kuşu sonradan Senmurw ve Simurg olarak anılmıştır. (S. Alsan, 2017:112)

Görüldüğü üzere oldukça derin bir tarihi geçmişe sahip olan ve aynı zamanda geniş bir coğrafyayı içine alan bu kuş ve içinde yaşadığı efsaneler oldukça yaygındır. Bu denli birbirine benzer özelliklere sahip olan Zümrüdü Anka; Sîmurg, Garuda, Phoenix, Gaokerana, Karakuş vb. isimlerle anılan bu doğaüstü yaratığı herhangi bir millete maal etmek olanaksız olsa gerek. Bu kuşun içinde geçtiği efsaneleri bünyesinde barındıran medeniyetlerin kültürler zenginlikleri, dili, dini ve ırk1 ayrıda olsa ortak bir noktaları Âdemoğlu olmalarıdır diyebiliriz.

Hayali ve efsanevi bir kuş olan Zümrüdü Anka/Sîmurg kuşu hem İslam öncesi hem İslam sonras1 efsanelerde yer almaktadır. İslamiyet'in kabulünden sonraki evrelerde ortaya çıkan efsanelerde yer alan Zümrüd-Anka- Simurg kuşunun birçok örneği görülmektedir. Kültürler zaman 
ve mekân değişse de bu olağan üstü özelliklere sahip ve bir okadar güzel kuş farklı isimlerde farklı efsanelerde siklıkla görmekteyiz.

Farklı kültürlerde Anka, Simurg, Phoenix, Garuda, Grifon gibi isimlerle de anılan bu fantastik hayvan olağanüstü vasıflara sahiptir. Phoenix esas itibariyle Misır mitolojisinde, Simurg ise İran mitolojisinde görülür. Bunun Arap-İslam kültüründeki yansıması Anka ya da Zümrüdüanka'dır. Garuda ise Hint mitolojisinde yer alır (Ateş, 2017: 217).

Arapların mitolojik kuşu olan Anka'nın, Kâf dağında; İranlıların Sîmurg olarak adlandırdıkları bu kuşun ise Elburz dağında yaşadığı rivayet edilir. Efsaneye göre Anka otuz kuşun özelliğini taşıdığı için "sîmurg", otuz çeşit rengi bulunduğu için "sîreng" olarak adlandırılmıştır. Renginin yeşil olduğuna inanıldığ iç̧in "Zümrüdüanka" adıyla da anılmıştır (Oener, 2018).

Anka; tüyleri güzel, boynu uzun, kendisi büyük bir kuştur. Boynu halka halinde beyaz tüylerle çevrilmiş olduğu için Anka denilmiştir. Anka; gerdanlık demektir. Anka kuşu gözle görülmeyecek kadar yükseklerde uçmaktadır (T. Apak, 2015).

Zümrüdü Anka kuşunun yaşadığı rivayet edilen Kaf Dağı ya da Elburz dağında kuşun yuvasının üzerinde bulunduğu görkemli bir ağaçtan bahsedilir. Bu ağaç bazı kaynaklara göre kavak ağacı, bazı kaynaklara göre çınar ağacı, bazılarında ise hayat ağacı şeklinde geçmektedir.

Firdevsi'nin (ö. 1020) eski İran efsaneleri üzerine kaleme aldığı ünlü destanı Şehnâme'de olağanüstü özelliklere sahip iki ayrı Sîmurg'tan bahsedilir. Biri Zâl destanının kahramanı olan Zâl'i besleyip büyüten iyi Sîmurg; diğeri İsfendiyar hikâyesindeki Ehrimen taraftarı olup insanlara zarar veren ve İran'ın düşmanı olduğu için, İsfendiyar tarafindan öldürülen kötü Sîmurg'tur (Oener, 2018).

Anadolu halk kültüründe ve ürünlerinde "Anka” olarak bildiğimiz kuş, Kıbrıs masallarında "Zümrüdüanka" olarak geçmektedir. Olumlu bir imaj olarak karşımıza çıkan Zümrüdü Anka kuşu eşi benzeri olmayan güçlü yapısı ile ve gaybı bilen zeki bir kuş olarak karşımıza çıkar (Ateş, 2017: 217).

Türk mitolojisinde önemli bir yeri olan Er -Töştük Destanında bahsedilen kara-kuşun Simurg ve Garuda kuşları ile benzer özellikler taşıdığı dikkatte değerdir. Hikayeye göre; Er -Töştük Destanında anlatılan kara-kuş; kendini ve yavrularını beslemek için avlanmaya gidermiş. Kara-kuş avlanma sırasında yuvasındaki yavrularını yalnız bırakmak zorunda kalırmış. Yine Kara-kuşun avlanmaya gittiği bir vakit yuvayı belleyen ejderha yavru kuşları yemek için saldırmış. O sırada Çınar ağacının altında dinlenmekte olan Er-Töştük ( Ertürk) bu olayı görmüş ve hemen kılıcını çekip ejderhaya hücum etmiş. Kılıcı ile ejderhanın başını gövdesinden ayıran Er-Töştük, yavruları son anda yem olmaktan kurtarmış. Tamda bu esnada Kara-kuş tüm heybeti ve göğü karartan kanatları ile yuvaya konuvermiş ki yuvasından aşağı inen Er-Töştük'ü görmüş. Kara-kuş ağzındaki yiyecekleri yavruların önüne bırakıp, ağaçtan inmekte olan Er-Töştük’ü bir hamlede iki gagasının arasına almış. Kara-kuş yuvasına çıkan bu haini havaya firlatarak yutmaya hazırlanırken yavru kuşlar dile gelip ErTöştük'ün masum oldugunu, hatta onları ejderhadan kurtardıklarını söylemişler. Kara-kuş Hayat ağacının altında yatan kesik başlı ejderi görünce Er-Töştük'ü masum olduğuna kanaat getirmiş ve bu iyiliği karşısında Er-Töştük'e dileğini sormuş. Er-Töştük'ü Kara-kuştan onu yeryüzüne çıkartmasını istemiş. Kara-kuş bu isteği yerine getiririm fakat yeryüzüne çıkana kadar ben gak deyince et guk deyince su vereceksin demiş. Er-Töştük Kara- kuşun bu isteklerini hazırlamış ve yola çıkmak için Kara-kuşun boynuna oturmuş. Kara-kuş gak demiş kahraman et vermiş, guk demiş su vermiş, tam yeryüzüne yakın bir mesafede et bitmiş. Er-Töştük çok üzülmüş fakat çaresiz belindeki kuşaktan çakısını çıkartarak baldırını kesip Kara-kuşun ağzına atmış. Nihayet yeryüzüne çıkan Kara-kuş boynundan Er-Töştük indirmiş ki ne görsün delikanlının bacağı kanlar içindeimiş. Kara-kuş ErTöştük'ün yaptığı fedakârlığı anlar ve onu kanatları arasına alarak yaralarının iyileşmesini sağlamış ve vedalaşarak yuvasına dönmüş (C. Bayrak, kişisel iletişim, 2016). 
Er-Töştük Destanında kahramanın kuşun sırtında uçması, Hint mitolojisinde Vişnu'nun bineğini sembolize eden Garuda kuşuna işaret etmektedir. Kuşun insanı gençleştirmesi ve iyileştirme kudretinin oluşu da kendi küllerinden genç doğan Phoenizi hatırlatmaktadır (Çoruhlu, 2014:9).

Anadoluda yazılmış mühim bir eser olan Saltukname'de de Simurg il ilgili hususlar vardır. Burada Simurg Er-Töştük destanındaki kartal ile Garuda'nın bir sentezi olarak görülür. Saltuknamede de Sarı Saltuk Kafdağı'nda bulunan büyük bir ağacın yanına gelir. İslamiyet öncesinin kutsal kayın ağacını veya diğer doğu mitolojisindeki dünya veya hayat ağacını hatırlatan bu ağacın üzerinde Simurg'un yuvası bulunmaktadır. Simurg yiyecek aramaya çıkar. Onun bu sefer getireceği yiyecek Garuda ile ilgili efsanede olduğu gibi fil olacaktır. Sarı Saltuk Simurg yiyecek getirmeye gittiği sırada, onun yavrularını, kendine yem yapmak isteyen ejderhanın elinden kurtarır. Az sonra gagasında iki fil taşıyarak gelen Simurg Sarı Saltuk'u öldürmek isterken yavruları buna mâni olur (Çoruhlu, 2014:9).

Zümrüdü Anka/Sîmurg bu efsanevi yaratık medeniyetler tarafindan farklı özelliklerle anılmasının yanın sıra maneviyat ve huy olarak'ta birbirinden farklılık göstermektedir. Simurg'u kimi efsanelerde, iyi huylu, cesur akil ve adaletli bir varlık olarak görürken bazı efsanelerde kötü huylu, kötülerin dostu, zulüm saçan şeytani bir canavar olarak görmekteyiz.

İslamiyet'ten sonraki Türk sanatında hayvan sembolizmi söz konusu olduğu zaman, bu bölüm ile ilgili olarak, Garuda yerine daha ziyade Simurg' dan söz etmek gerekecektir. Çünkü Simurg Tasavvuf ve Edebiyat 'ta olduğu gibi, Türk sanatında da çok önemli bir sembol olarak karşımıza çıkmaktadır. Konumuz bakımından onun en yaygın tasvir alanı minyatürlerdir. Bunlar arasında Firdevs'inin Şehnamesi'nin minyatürleri başta gelir (Çoruhlu, 2014:12).

Şehname'de Simurg'un Zal'ı büyütmesi özetle şöyle anlatılır: Zal bebek olmasına rağmen bir yaşlı çocuk olarak doğunca, babası Sam onu istemez ve ortadan kaldırılmasını emreder. Hükümdarın adamları çocuğu alıp Elburz dağına bırakırlar. Simurg'un yuvası da buradadır. Yavruları acıkınca yuvasından çıkan bu efsanevi kuş, bir taşın üzerinde ağlamakta olan bebek Zal'i bulur. Onu alıp yuvasına götürür. Bu arada Simurg'un kulağına Allah tarafindan, bu çocuğu iyi koruması gerektiği ve onun soyundan cihan pehlivanların yetişeceği fisıldanır. Simurg çocuğu büyütür. Yıllar sonra oğlunu rüyasında gören Sam, çocuğunu almaya Elburz dağına gelir. Neticede Zal ile vedalaşan Simurg yardım gerektiğinde kendisini çağırmak üzere kullanacağı bir tüyünü ona verir. Babası ağlayarak Simurg'a şükranlarını bildirir ve çocuğu alıp götürür (Çoruhlu, 2014:12).

Şehname'de Simurg'un Zal ile olan ilişkisi çok güçlü bir betimleme ile verilmiştir. Sam oğlunu bulmak için gittiği Elburz dağında, Simurg ile karşılaştığında oğlunu simurg' dan isterken tüm pişmanlığını ve mahcubiyetini göstererek onu bir daha incitmeyeceğini ifade etmeye çalışmıştır. Yine Simurg çocuğu babasına teslim etmeden Zal ile yaptığı konuşmada "benimle kalman benim için iyi ama babanla gitmen senin geleceğin için iyi bu sebepten seni ona teslim ediyorum ama her ne zaman ihtiyaç duysan, senin yanında olacağım" der. Simurg'un Zal'a duyduğu bu şefkat ve sevgi, bir annenin evladına duyduğu sevgi ile ilişkilendirilebilir..

İslamiyet'ten sonra Simurg'un tasavvufi bir sembol olarak yorumunu, Ferideddin' Attar'ın Mantıku't-Tayr'ı ile Nevai'nin bunu örnek alarak yazdığ 1 "Lisanü’t- Tayr" da buluyoruz. Ayrıca yine Attar'ın eserini örnek alan, Gülşehri'nin "Mantıku't-Tayr'ında da aynı konu yer almaktadır. Bütün bu eserlerindeki ana fikir, tasavvuftaki "varlıkta birlik" (Vahdet-İ Vücut) düşüncesine dayanmaktadır. Evrende yalnızca bir vücut vardır. Bu vücud, vücud-1 mutlak olan Allah'tır. Onun dışında görünen her şey, Allah'ın bir ayna olarak düşünülen "adem-i mutlak" ile karşılaşmasından oluşan görüntülerdir. Allah çeşitli şekilde ve sürekli olarak tecelli ettiği için bütün eşya ve yaratıklar gerçekmiş gibi görünürler (Çoruhlu, 2014:13). 
Ferideddin' Attar'ın eserinde ve yine onun eserinden ilham alan yazarların eserindeki “ana fikir, temsili olarak Simurg ile anlatılmaktadır" diyen Yaşar Çoruhlu "Simurg burada Allah'ın tecelli etmesinin sembolü olmaktadır" der.

Hikâyeye göre; Dünyadaki tüm kuşlar İspinoz, Hüthüt, Karga, Balıç̧ıl, Dul Kuşu, Çit Kuşu, Kral Sinekkapan, kırlangıç, Martı, Doğan, Karabatak, Ardıcı, Pelikan, Çalıkuşu, Tavus, Bülbülü, Kaz, Akbaba, Kartal, Şahin saymakla bitmez daha pek çok kuş, toplanarak istişare etmişler ve kendilerine bir padişah seçmeye karar vermişler. Hz. Süleyman'ın postacısı olarak da bilinen, Hüthüt kuşu söz alarak kuşlara aslın da bizim bir padişahımız var demiş. Kuşlar heyecan ve merak içinde Hüthüt'e padişahımızın adı nedir? diye sorarlar. Hüthüt kuşlar padişahının adının Simurg olduğunu, onun Kafdağı'nda yaşadığını, tüm kuşları ayırmaksızın her daim onlara çok yakın olduğunu söylemiş. Kuşlar padişahlarını ziyaret etmek ve onu görmek istediklerini dile getirince, Hüthüt onlara kılavuzluk edebileceğini ancak gidecekleri yolun oldukça zahmetli ve sabır gerektiren bir yol olduğunu söylemiş. Tüm kuşlar başta kabul etmişler fakat yola çıktıktan bir süre sonra kuşların kimi hasta olmuş, kimi gurbete dayanamamış, kimi ise arzularının peşinden gitmiş. Bu gibi pek çok sebepten ya geri dönmüşler ya da yolda ölmüş. Kuşlar padişahına giden bu uzun ve çilelerle dolu yolu geçmeyi ancak otuz kuş başara bilmiş. Kafdağı'na ulaşan otuz kuş, orda kendilerinden başka hiçbir şey bulamamışlar ve anlamışlar ki Simurg kendilerinden başkası değil. Birçok bedendede olsa, tek vücut olabilmek bir olmanın naif gücünün simgesi gibidir. Vahdet-i Vücut, düşüncesine dayanan bu anlayışa göre; Simurg, Yüce yaratıcının tecellisinden başka bir şey değildir.

Gerçekte var olduğu bilinmeyen Zümrüdü Anka kuşu, pek çok efsane ve hikâyede geçmektedir. Simurg, Phoenix, Zümrüdüanka, Garuda vb. isimler ile anılan ve herhangi bir topluma mal etmek olanaksız olduğu gibi, bu efsanevi kuşu iyi- kötü şeklinde belli bir kalıba sokmakta oldukça yanlış olacaktır. Yazma kitaplarda metin aralarını süsleyen minyatür eserlerde daha çok karşımıza çıkan ve bu sayfalarda hayat bulan bu efsanevi kuş, pek çok toplum tarafından benimsenerek kendi kültürleri içerisinde yer almıştır.

\section{Simurg-Zümrüdü Anka veya Garuda'nın Görsel Sanatlardaki Bazı Yorumları}

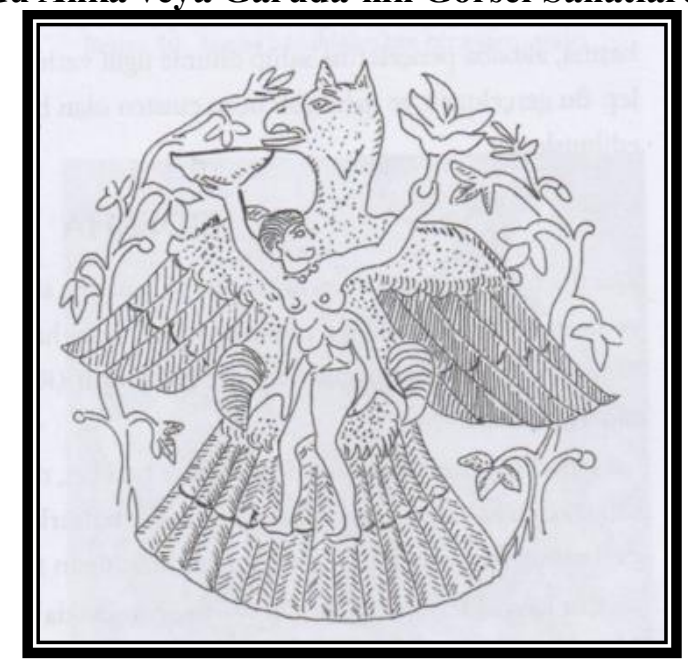

Şekil1:1- Peçenek Türklerine Ait Nagyszentmiklos Hazinesindeki 7 Numaralı Sürahide Bulunan Garuda (karakuş) Figürü. Çizim; Yaşar Çoruhlu (Çoruhlu, 2011:171).

Bu tasarımda Simug sanki havada uçar gibi, iki kanadını ve kuyruğunu açmış bir biçimde betimlenmiştir. Yaşar Çoruhlu hocamız" Garuda'nın ( Karakuş?) bir kartalın gagası, pençeleri ve başına sahiptir" diye yorumlamıştır. Garuda'nın etrafındaki dal ve yapraklardan oluşan bitkisel motifin üzerinde yaşadığı Hayat ağacının bir sembolü olsa gerek. Garuda'nın pençeleri arasında itinayla tuttuğu çıplak insan figürü kadını anımsatmaktadır. Kadın sağ eli ile Garuda'nın ağzına 
doğru bir kâse tutarken sol eli ile de hayat ağacının bir dalını tutmaktadır. Güç ve iyiliğin timsali Garuda (Simurg?) uzun ömür ve bereketin simgesi, hayat ağacı ve doğurganlığın simgesi kadın, figürlerinin bir arada kullanıldığını görüyoruz (şekil:1).

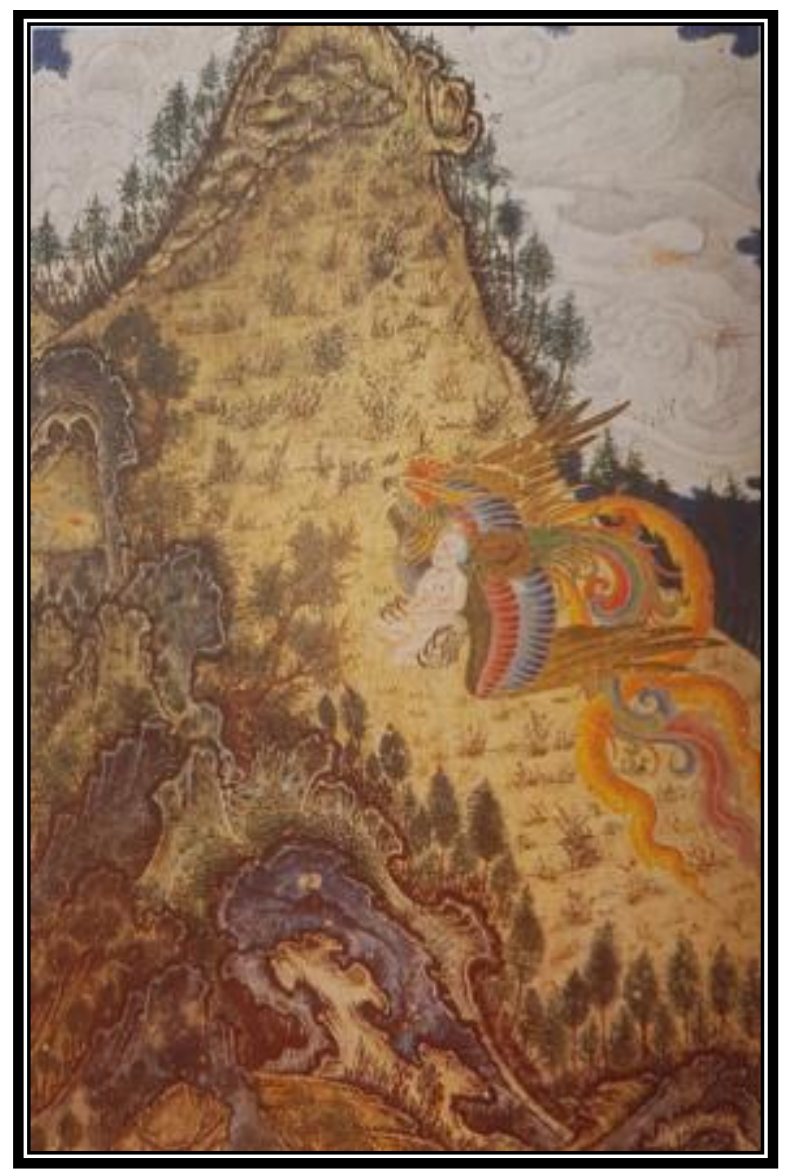

Şekil: 2- Türk minyatür sanatı (Başlangıctan Osmanlı'lara kadar), (İnal: 1995 sayı:63)

"Firdevs'inin, Şehnamesinde" bulunan minyatür eser, tam sayfa dikdörtgen planlı tasarlanmıştır. Hikâyeye göre; Sam oğlu doğunca bakar ki bembeyaz saçlı ve kirpikli, buruş buruş, bunu kabullenemez ve kimse görmeden bebek Zal' 1 askerleri ile Elburz dağına gönderir. Elburz dağının eteklerinde ağlayan bebek Zal'ı Simurg bulur ve yuvasına götürerek ona bakar ve büyütür. Bu minyatürde, hikâye metninde anlatılan, Elburz dağına terkedilen Zal'ın Simurg tarafindan bulunup yuvasına götürme anı canlandırılmıştır (Şekil:2).

Minyatür de Simurg dağın eteklerinden, dağın zirvesindeki yuvasına doğru uçarken iki kanadı acık, kanat çırpar bir vaziyette resmedilmiştir. Simurg'un heybetli kuyruğu sayfaya sığmamış bir biçimde görülmektedir. Simurgun kuyruğunda helozonik kıvrımlar ve bu kıvrımlar arasından çıkan dalgalı uzun tüyler ile betimlenirken mavi, yeşil, kırmızı, turuncu ve altın yaldız ( altın) renkleri kullanılmıştır. Kuyruk kısmında kullanılan bu renkler, kuşun kanat ve vücudunda dengeli bir biçimde dağılım göstermektedir.

Simurg'un Pençeleri arasında Zal yaşlı bir adam görünümünde resmedilmiştir. $\mathrm{Bu}$ betimleme bebeğin babası Samın gözünde Zalın görünüşü olsa gerek. Beyaz saçlı beyaz kirpikli ve beyaz tenli doğan Zal bir Albino dur. Simurg un arka planında, üzeri çam ve çınar ağaçlarıyla kaplı 
Elburz dağından bir kesit verilmiştir. Elburz dağının zirvesinde beyaz ve giri bulutlarla kaplı gökyüzü betimlenmiştir(Şekil:2).

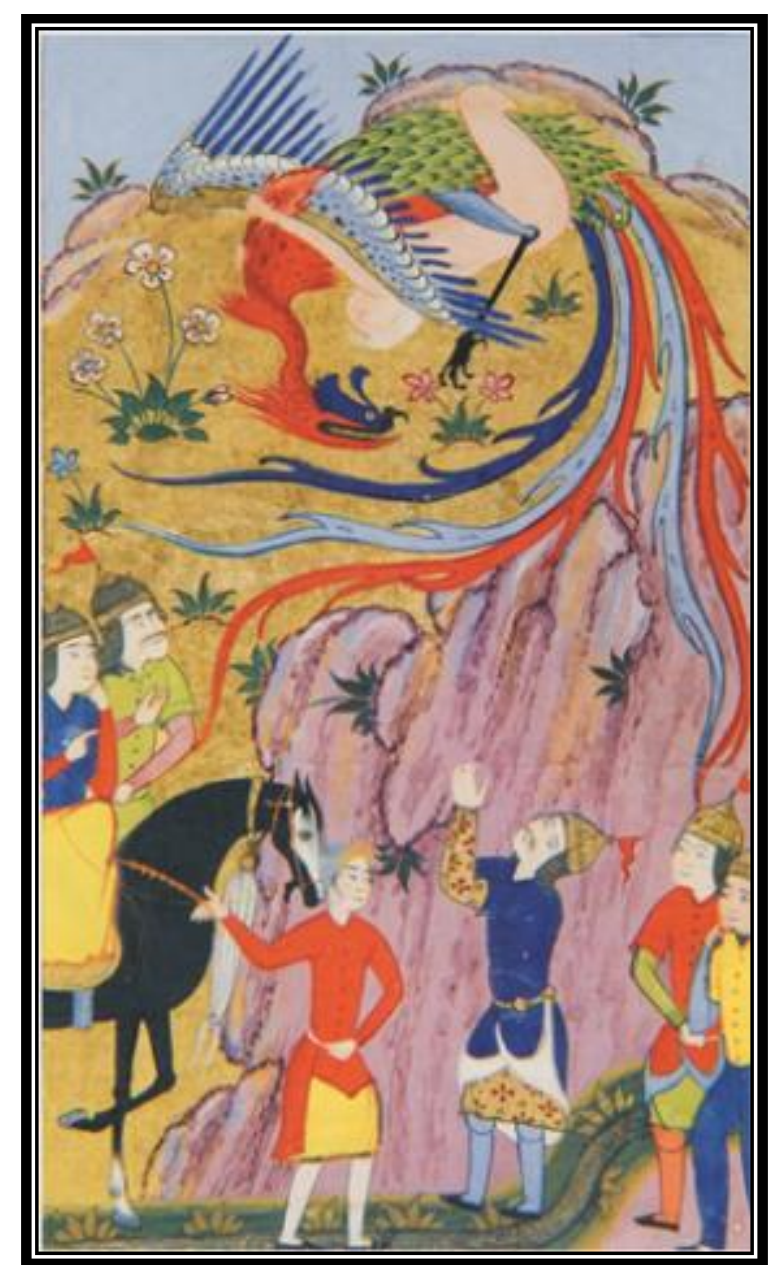

Şekil 3: Şehname, Simurg'un, Zal'ın, Aşağıda Hayretle Kollarını Kaldırmış Olan Babası Sam'a Getirmesi. (And, 1998:318)

"Firdevs'inin, Şehnamesinde" bulunan bu minyatür eser, dikdörtgen planlı ve tam sayfa biçiminde resmedilmiştir. Minyatür tasarımda, zemin üzerinde, Sam iki askeri ve bir yardımcısı ile ayakta durur pozisyonda, iki askeri ise at üzerinde çizilmiştir. Sam kollarını havaya kaldırarak oğlu Zal'i tutmayı hedefler bir planda, başı göğe doğru, gözleri Simurg ve Zal üzerinde betimlenmiştir. Yardımcı sağ eli ile atın yularını tutarken gözleri Sam'ın üzerinde, Sam ve dört askeri ise başlarını yukarı doğru kaldırmış, Simurg'u izler vaziyette çizilmiştir. Figürlerin yüzlerinde hafif bir gülümseme ve hayret ifadesi görülmektedir. Sam ve dört askerinin başında tolga ( miğfer) yardımcının başında ise kask biçiminde bir şapka takılıdır. Figürler dönemini yansıtan kıyafetler içinde çizilmiştir. Minyatür tasarımın arka planında Elburz dağından bir kısım ve zeminde etrafı yapraklarla bezenmiş ince kıvrımlı bir dere görüntülenmiştir ( Şekil: 3).

Simurg gövdesine sarılı Zal'ı aşağı doğru indirirken görüntülenmiştir. Simurg yukardan aşağı süzülürken sol kanadı ve bacağı ile Zal'ı tutmaktadır. Kuşun uzun boynu ve yere kadar uzanan ihtişamlı kuyruğu Simurg'un ayırt edici özelliklerindendir. Simurg'un kuyruğunda lacivert, buz mavi ve kırmızı olmak üzere üç renk kullanılmıştır. Kuşun kuyruğunda kullanılan bu üç renk, kanatlar, baş ve boyunda tekrarlanırken, gövdesinde açık yeşil renk görülmektedir. Zal iri gövdeli beyez saçlı 
(albino) beyaz tenli, çıplak bir biçimde kolları ve ayakları ile Simurg'a sarılmış bir görünüm içindedir (Şekil :3).

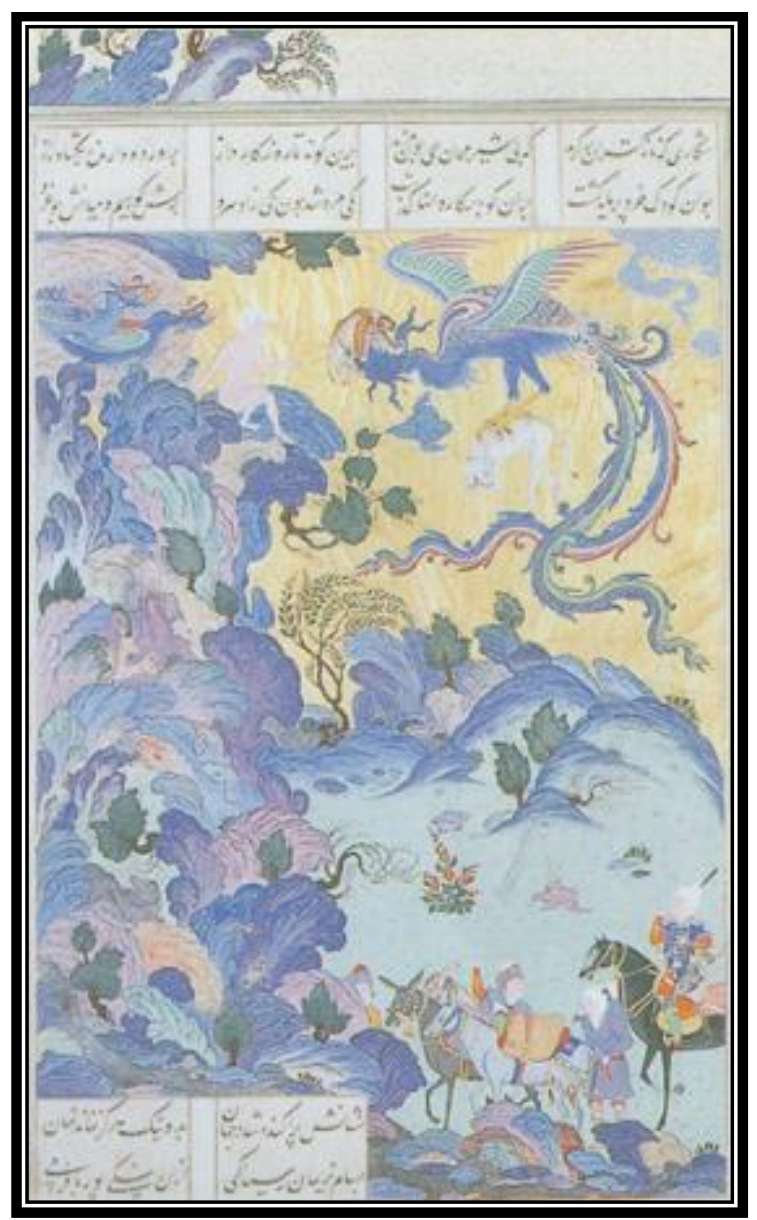

Şekil 4: Sam'in Kervanla Zal'ı Almaya Gelmesi (Firdevsi, 2017:1070).

"Firdevs'inin, Şehnamesinde" bulunan bu minyatür eser, yine dikdörtgen planlı ve tam sayfa şeklinde resmedilmiştir. Kompozisyonda Simurg, kanatları açık gökyüzünde uçarken görüntülenmiştir. Avdan gelen Simurg'un pençelerinde, beyaz renkli iri bir dana (inek yavrusu) vardır. Simurg'un ağzı açık tasviri, yavruları ve Zal'a yemek getirdiğini haber vermek için seslendiğini göstermektedir. Gökyüzünü kaplayan Simurg'un heybetli kuyruğu yere doğru yaklașık dört insan boyundadır. Saz yapraklarını andıran kuyruğunda mavi, pembe, kırmızı ve yeşil renkler kullanılmıştır. Yine kuyrukta kullanılan renkler Simurg'un tüm vücudunda dengeli bir biçimde kullanılarak renklendirilmiştir (Şekil:4)

Minyatür tasarımda, görkemli Elburz dağı sayfanın neredeyse yarısını kaplamaktadır. Dağın zirvesine yakın bir tepesinde, büyük bir kuş yuvası, yuvanın içinde iki Simurg yavrusu görülmektedir. Yavruların ağzının açık olmasından onların acıktığını ve kanat çırpmalarından anne Simurgu görmenin heyecanını yaşadıkları aşikârdır. Yuvanın hemen dışında tepenin kıyısında oturmuş Zal'ı görmekteyiz. Beyaz saçlı ve açık tenli ( albino) Zal çırılçıplak sağ eliyle tepedeki taşlardan tutunurken sol elini ise Simurg'a uzatmış bir biçimde resmedilmiştir.

Sayfanın alt ön kısmında, zemin üzerinde Sam üç adamı ve dört at ile görüntülenmiştir. Sam'ın üç askeri ayakta durur pozisyonda, kendisi ise at üzerinde tasarlanmıştır. Bu minyatürde bir 
öncekinin aksine Sam ve tüm adamlarının başlarında sarık görülmektedir. Sam başındaki sarığında hükümdarlık alameti olan sorguç ile çizilirken, Tüm figürler dönemini yansıtan kıyafetler içinde çizilmiştir. At üzerindeki Sam sağ elini ağzına götürmüş hayret ifadesi ile çizilirken, ayaktaki adamlarından biride sağ eliyle gökyüzündeki Simurg'u işaret ederken telaş içinde tasvir edilmiştir. Minyatür tasarımda, ağaçlarla kaplı, Elburz dağının renklendirilmesinde mavi ve tonlarının yoğunluğu dikkat çekerken, tüm gökyüzü altınla kaplanmıştır (Şekil:4).

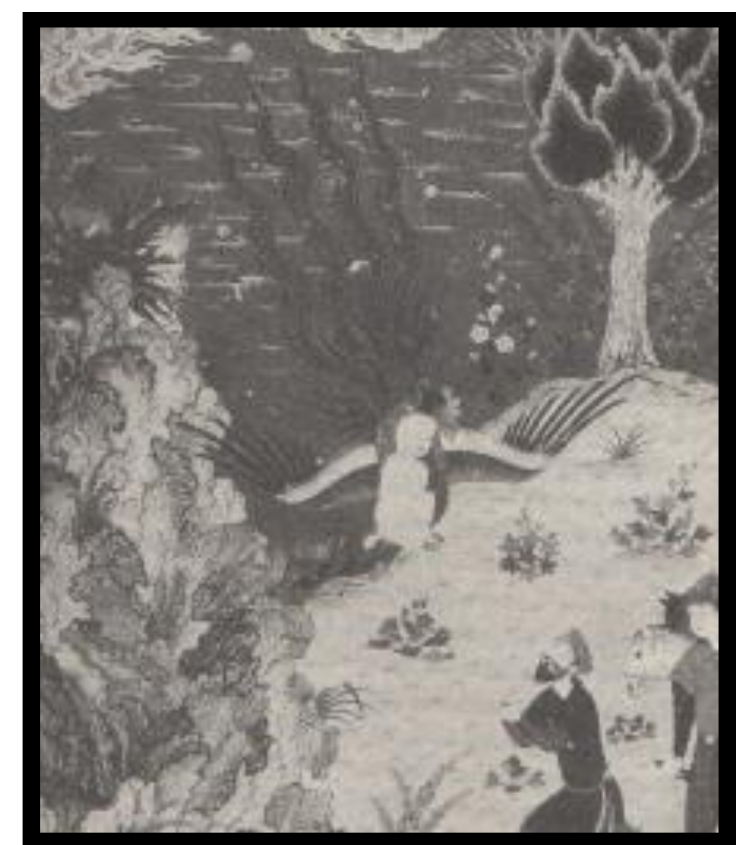

Şekil 5: Sam'ın Oğlu Zal'ı Almaya Gelmesi (Firdevsi, 2017:158).

Yine "Firdevs'inin, Şehnamesinde" bulunan minyatür eserde Samın oğlu Zalı almaya geldiği an canlandırılmıştır. Sayfanın solunda, zirvesinde heybetli bir koca çınarın bulunduğu tepe üzerinde, Sam başında tacı, dizleri üzerine oturmuş iki kolu yukarı doğru açık bir biçimde Simurgun getireceği oğlunu heyecanla beklerken görüntülenmiştir. Samın arkasında sayfaya sığmayan bir asker ve atı görülmektedir.

Elburz dağının eteklerinde tasarlanan minyatürün sol bölümünde zirvesi girift bulutlarla kaplı, zeminden gökyüzüne kadar uzanan Elburz dağ1 görüntülenmiştir. Sayfanın tam ortasında, yukardan aşağı doğru süzülen Simurg pençeleri arasında Zal'ı itinayla taşırken çizilmiştir. Bu sayfadaki Simurg çizimi Zal figürünün arka planında kaldığı görülmektedir. Sanatkârın Zal'a vurgu yapmak için figürü oldukça iri çizildiği açıkça görülmektedir. Diğer Simurg çizimlerinin aksine burada kuyruğun yukarı doğru uzanması iki şekilde açıklanabilir ki, birisi hızla inen kuşun rüzgârın ve hızın etkisinde kaldığı fikri, diğeri kuşun kuyruğunun uzunluğu ve ihtişamının gözler önüne serilmek istenmesi diyebiliriz. Bu durum yoruma açık olsa da pençelerinde itina ile taşıdığ bebek Zal'ı bu denli bir hızla yere indirmeyeceği düşüncesi ile kuşun ihtişamına dikkat çekilmek istendiği fikrini aklımıza getirmektedir. (Şekil:5) 


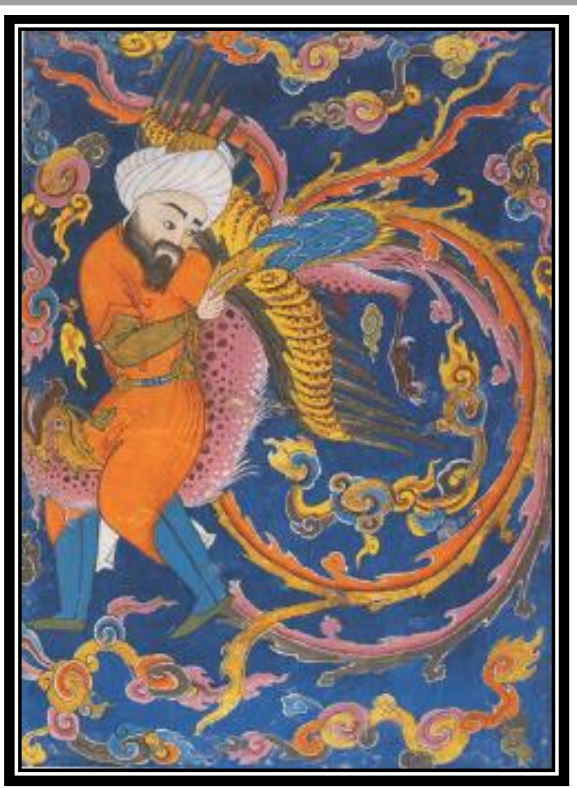

Şekil 6: Bukratın ( Hipokrat) Simurg'a binip ilaç almak için Kaf Dagına gitmesi ( Falname. TSM H. 1703) (And, 1998:319).

Falnamede bulunan minyatür koyu mavi zemin, gökyüzünü simgelemektedir. Simurg, gökyüzünde bulutlar arasında uçar bir biçimde görüntülenmiştir. Simurg'un kartal gagası ve kartal başını anımsatan kafası, yukarı doğru yönelmiş, tepesi ibikli, gözleri küçük ve ağzı açık bir hareket planında tasvir edilmiştir. Beneklerle bezeli, pembe renkli iri gövdesi, kırmızı noktalarla süslü sarı veya altın kanatlarını, uzun ve görkemli kuyruğu tamamlamıştır. Simurg oldukça esnek ve kıvrak bir görüntü sergilemektedir. Kuşun kuyruğundaki sarı, turuncu, altın ve açık pembe renkler tüm vücutta kullanılırken, kuyruk kökündeki tüyler mavi ile renklendirilmiştir. ( Şekil:6)

Simurg'un boynunda Hipokrat görülmektedir. Hipokrat'ın düşmemek için sağ eli ile Simurg'un bir tüyünü tutarken, sol kolunuda Simurg'un kanadı altına sokarak sarılmış bir pozisyonda görüntülenmiştir. Hipokrat figürü oldukça iri ve düşünceli bir tavır içinde görünmektedir. Hipokrat başında sarık, belinde altın penç motifli mavi kemeri, turuncu bir entari ve mavi pantolon ile betimlenmiştir.( Şekil:6)

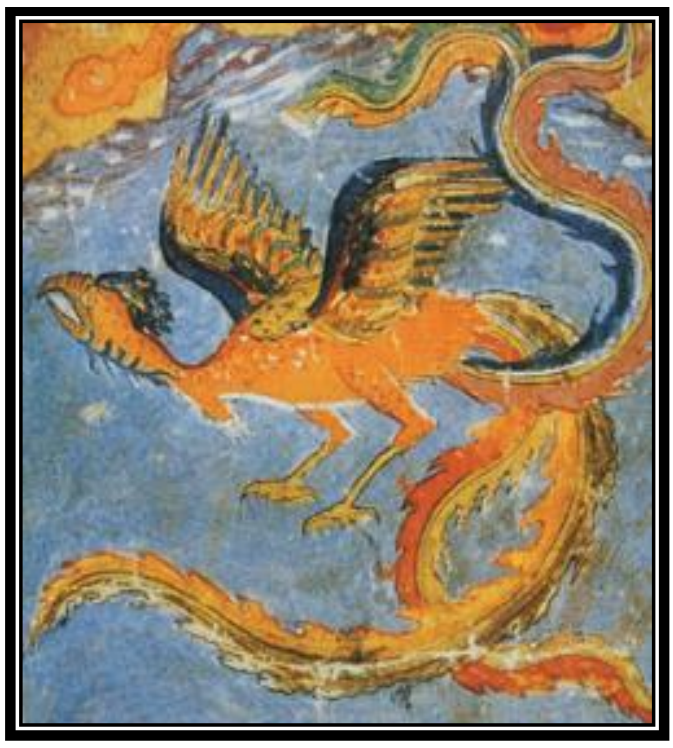

Turkish Studies - Social Sciences Volume 14 Issue 6, 2019 
Şekil 7: Simug (Acaibül- Mahlukat, BL.Or. 7315) (And, 1998:316)

Acaibül- mahlûkat adlı eserde bulunan bu minyatürde, Simurg mavi bir gökyüzünde uçarken görüntülenmiştir. İri gövdesini taşıyan iki kanadı açık kanat çırpar vaziyettedir. Uzun bacakları ve dört tırnaklı pençeleriyle sanki bir yere konmaya hazırlanır bir hareket planında çizilmiştir. Tepesi ibikli ve gagası açık olan Simurg, çığlık atıyor hissi uyandırmaktadır. Sağa, sola, öne ve arkaya uzanan ihtişamlı kuyruğu, neredeyse gövde uzunluğunun üç katı kadardır. Simurg'un kuyruğunda altın, turuncu ve mavi olmak üzere üç renk kullanılmıştır. Kuyrukta kullanılan bu renk ve tonları Simurg'un tüm vücudunda ahenkli bir biçimde kullanılmıştır. (Şekil:7)

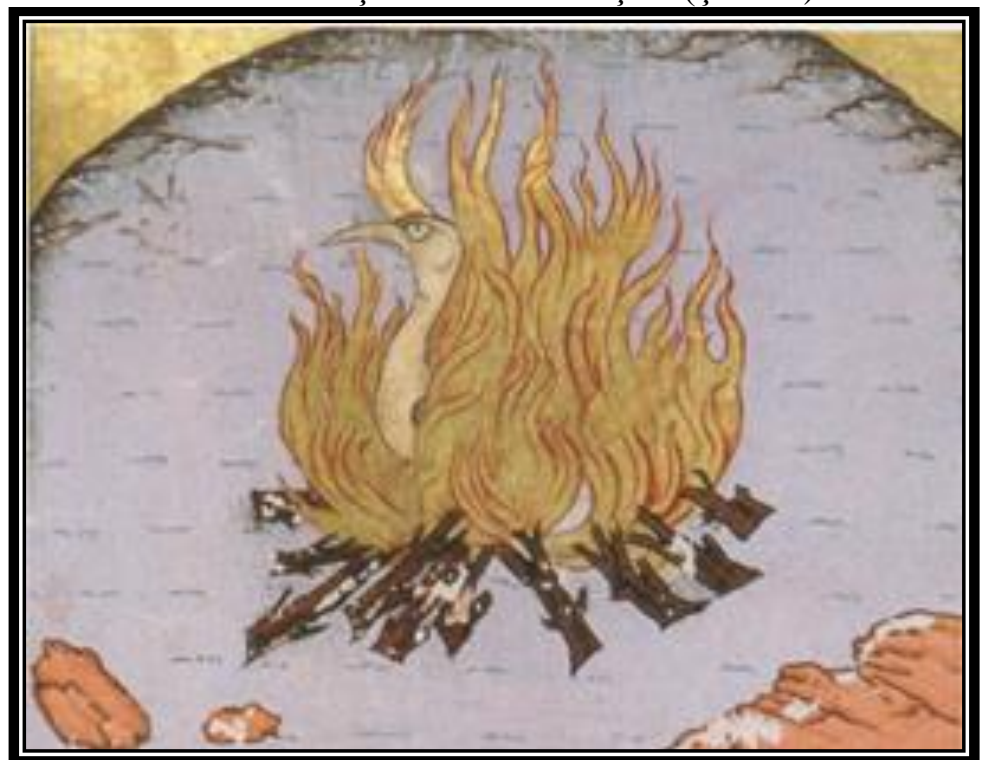

Şekil 8: Simurg Küllerinden Yeniden Doğmak Üzere Alevler İçinde ( Sanat ve Doğa Harikaları, BL. Harleian 5500) (And, 2004:413)

Metin And farklı efsanevi bir kuşun “Attar'ın eserinde geçtiğini bu kuşun adının Kaknus olduğundan bahsederken, Hint adalarında yaşayan, kanatları süslü, gagası delikli bir kuş” olarak tarif eder. Kaknus ölümü yaklaşınca çalı çırpı toplar, kanatlarını çırparak ateş çıkarır, ateşle çalı çırpıyı tutuşturup bu ateşin içine girerek yanıp kül olurmuş. Yağmur küllerin üzerine yağınca, küllerin içinden bir kurt çıkar külleri yer büyür ve yeni bir Kaknus oluşurmuş (And, 1998:316)

Küllerinden yeniden doğmak Simurg kuşu içinde bahsedilen bir hikâyedir. Simurgun yanıp kül olması sonucu kalan küllerin içinden Simurg'un yeni bir soyumu türüyor, yoksa aynı Simurg'mu vücuda geliyor bilinmez kaynaklar sadece "küllerinden doğan Simurg" şeklinde bahsetmiştir.

$\mathrm{Bu}$ minyatürde; Etrafı kayalıklı, mavi bir tepe üzerinde, alevler içinde, Simurg görüntülenmiştir. Çalı çırpıdan ziyade büyük ve kalın kütüklerin harladığ 1 ateş, göğe doğru yükselmiş, öğleki Simurg bu alevler arasında kaybolmuş, sadece başı ve boynu görülmektedir. Simurg'un görünen baş ve boyun kısmının renklendirmesinde açık bir ten rengi görülmektedir. Simurg'un tüyleri alevlerden yananmış ve kuşun teni ortaya çıkmıştır. Simurg'un yanıp kül olmak için girdiği ateş hem sonu hem sonun getirdiği yeni bir başlangıcı simgelemektedir. Simurg'un alevler içindeyken dahi, mağrur ve kararlı duruşunu, dimdik tuttuğu başı ve açıkgözlerindeki bakışlarından anlamak mümkün. Alevler içindeki Simurg'un acı çektiğine dair hiçbir ibarenin görülmemesi dikkat çekicidir. (Şekil:7) 


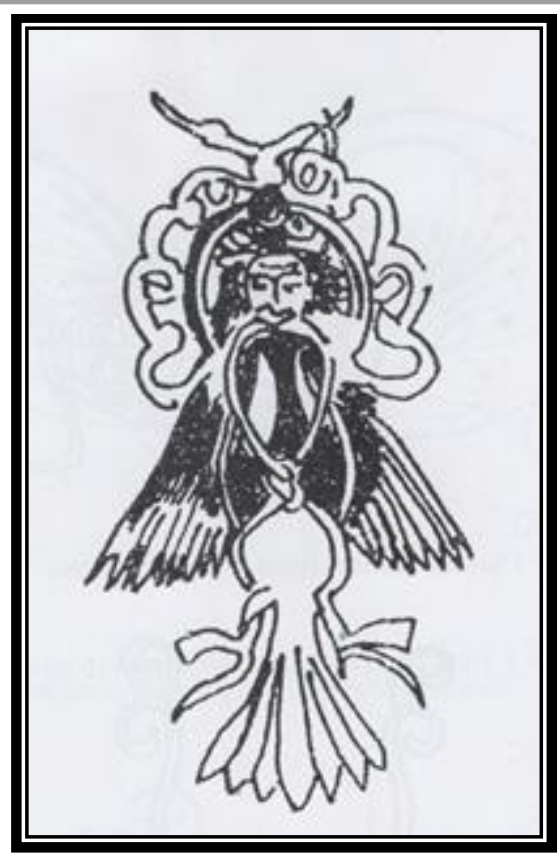

Şekil 9: Fresko Ayrıntısı. Garuda Tasviri. Kızıl, 7-8. Yüzyıl (Çoruhlu, 2014:258).

Çizimde; İnsan başlı ve insan gövdeli Garuda tasviri kuyruğu üzerinde ayakta durur bir biçim çizilmiştir. Garuda'nın arkasında şemse motifini andıran sembolik bir madalyon görülmektedir. Her iki kanadını kapalı bir biçimde iki yana bırakan Garuda tasvirinde gövde, bacaklar kol ve ayaklar ince şerit halinde gösterilmiştir. Kuyruğun iki tarafindan uzanan bacakların ayakucu üç tırnaklı pençe biçiminde tasarlanmışıı. Yine Garuda'nın kolları yukarı doğru kıvrık ve elleri yumruk biçiminde arkasındaki madalyonu tutar bir görünümdedir (Şekil-9).

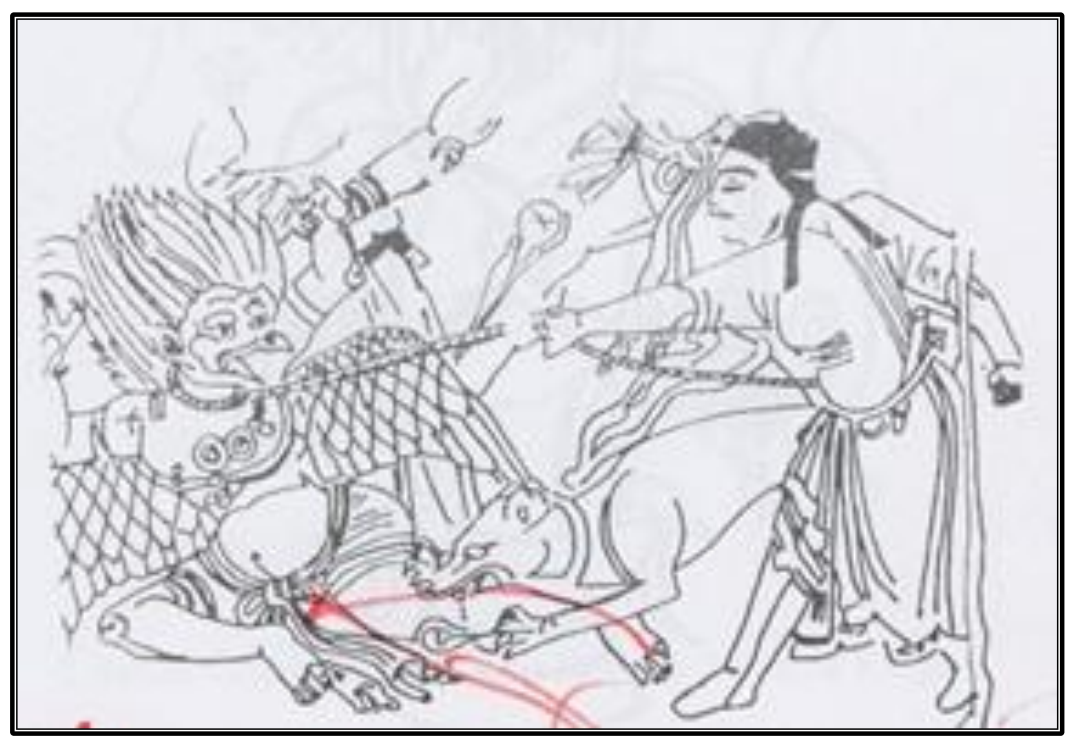

Şekil 10: Fresko. Alp Mabud Basaman Garudayı Yakalıyor. Bezeklik 9. Tapmak, 9-10. Yüzyıl (Çoruhlu, 2014:258).

9. ve 10. yüzy1llarla tarihlenen bezeklik'de İnsan vücutlu Garuda yere yıkılmış mücadele halinde tasvir edilmiştir. Garuda iki kolundan tutulmuş, boynuna halat geçirilmiş, sol bacağı bir köpeğin dişleri ve pençeleri arasında görülmektedir. Kötü karakterli Garuda'nın ağzı gaga biçiminde, 
saçları ise yukarı doğru uzanan iri tüylerle betimlenmiştir. Sahnede Garuda'nın içinde bulunduğu dehşet anı yüz mimikleri ile verilirken açık gagasıyla da çığlık attığını söylemek mümkündür. Garuda'nın sol kolunu tutan insan figürünün bir kısmı çizimde görülürken bu figürün iki eliyle Garuda'yı sımsıkı tuttuğu görülmektedir. Garuda'nın tam karşısında yer alan Alp Mabud Basaman sol kolunu öne uzatmış, Garuda'nın boynuna takılı halatı çekerken sağ kolunu arkaya doğru çekmiş halatın ucunu tutmaktadır. Figür 'ün sağ bacağı önde, sol bacağı geride, ellerinde tuttuğu halata bağlı Garudayı kontrol etme çabası içinde görüntülenmiştir. Alp Mabud döneminin giyim tarzını yansıtan yöresel kıyafetler içinde çizilmiştir (Şekil:10).

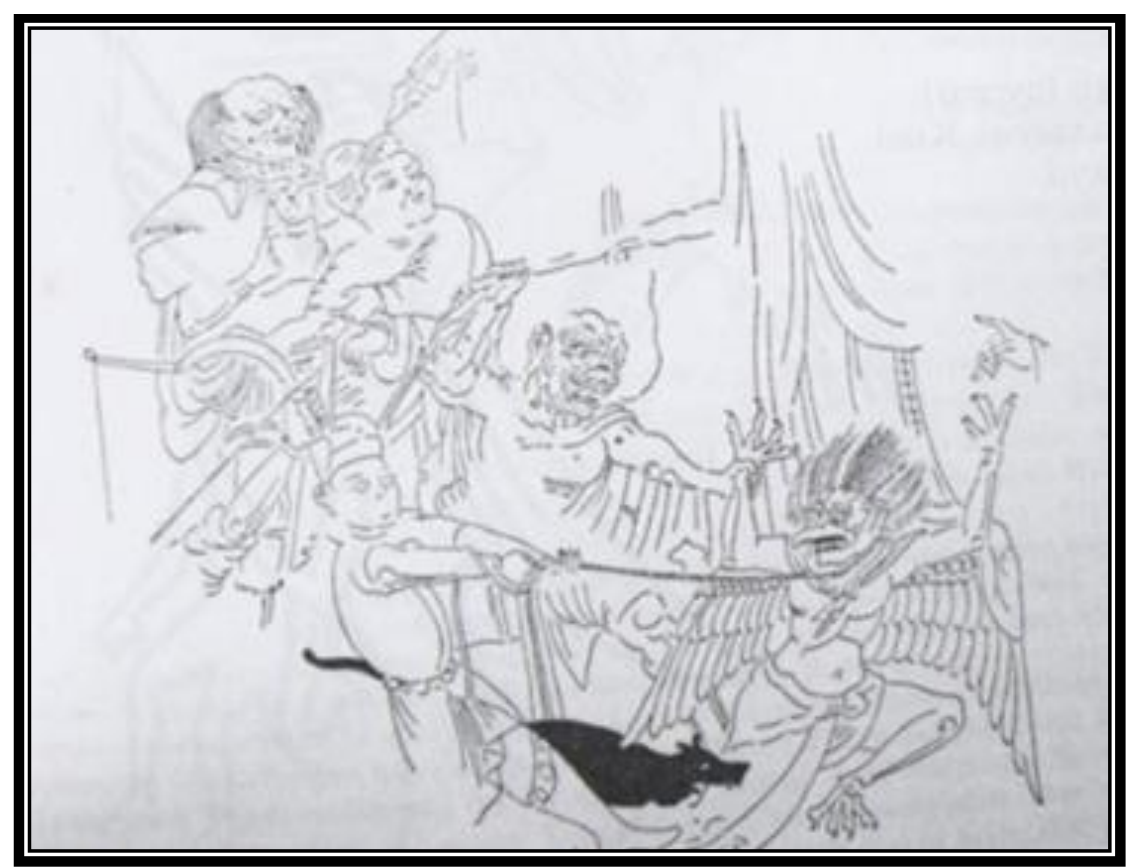

Şekil 11: Fresko, Basaman Garudayı ( Karakuş) Yakalıyor. Bezeklik Tapınakları, 9-10. Yüzyıl (Çoruhlu, 2014:259).

9. ve 10. yüzyıllarla tarihlenen bezeklik'de bir önceki Garuda tasviri farklı bir tasarımda tekrarlanmıştır. Garuda vücudu insan görünümünde, elleri üç tırnaklı, ayakları ise dört tırnaklı pençe şeklinde, ağzı gaga biçiminde, saçları yukarı doğru uzanan dik tüyler ve açık kanatlar ile tasvir edilmiştir. Garuda'nın yakalanma anı, boynunda halat, sağ bacağını kavramış bir köpek ve sağ bileğinden tutan doğaüstü bir yaratık ve yaratığın sağ elinde Garuda'ya vurmak üzere yukarı kaldırılmış bir sopa ile görüntülenmiştir. Garuda'nın içinde bulunduğu dehşet anı, yüz mimikleri ve vücut hareketleriyle oldukça güçlü bir anlatım sergilemektedir (Şekil:11).

Garuda'nın tam karşısında Alp Mabud Basaman iki eliyle Garuda'nın boynuna takılı halatı çekerken görülmektedir. Basaman Garuda'nın boynundaki halatı çekerken, sağ bacağından destek alarak kendini arkaya doğru hafif yatırmış bir hareket planında çizilmiştir. Basaman gözleri yuvasından fırlamış biçimde, hem Garudayı zapt etme çabası hem de şaşkınlık ve korku hali, gayet insani bir tepki içinde görüntülenmiş̧ir. Sahnede Garudayı hedef alan bir ok ve olan biteni izleyen iki figür tasarımın sağ üst köşesine yerleştirilmiştir. Sahnenin çeşitli yerlerinden çıkan el ve kol parçaları Basamanın kalabalık bir destekçisi olduğunun kanıtıdır. (Şekil:11). 


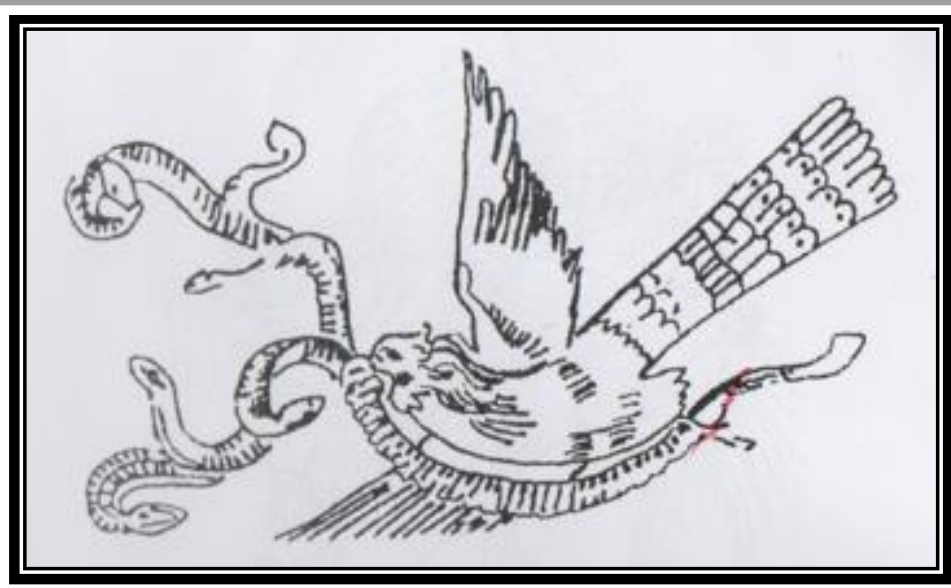

Şekil 12: Fresko ( ayrıntı). Garuda Tasviri. Kumtura ( ming-Öy Tapınakları 19. Tapınak), 8-9. Yüzyıl (Çoruhlu, 2014:259).

Fresko'dan alınan bu detayda; Garuda ağzında altı başlı bir yılan ile havada uçarken görüntülenmiştir. Yılanın boyunun Garuda'nın boyundan nerdeyse iki kat uzun olduğu görülmektedir. $\mathrm{Bu}$ denli uzun ve altı başa sahip olan doğaüstü yılanın, Garuda tarafindan zorlanmadan taşıması onun cesaret ve kuvvetine bir delil olsa gerek. Garuda'nın başı ve gaga tıpkı bir kartal gibi betimlenmiştir. Yine Garuda'nın boynundaki tüyler ve kanatları kartalı anımsatırken, kanatlarından uzun olan kuyruğu ile kartaldan ayrıldığı görülür. Burada kuyruğun şekli ve boyutu diğer Garuda, Simurg, Anka vb. kuş betimlemelerinden farklı olduğu dikkat çekmektedir. Bu çizimde Garuda çizimi daha çok, Türklerin Karakuşunu anımsatmaktadır(Şekil:12).

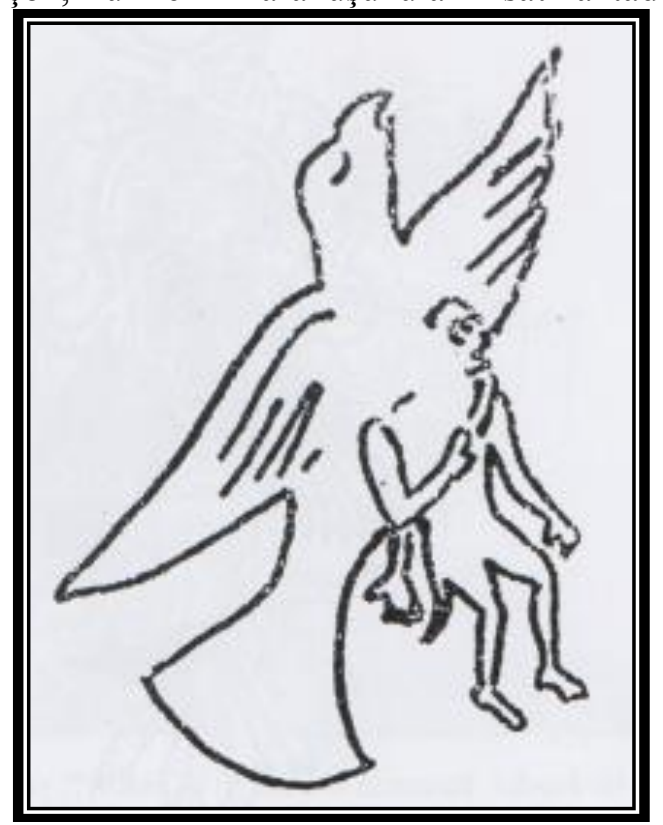

Şekil 13: Fresko (ayrıntı). Garuda Tasviri. Kızıl, 6-8. Yüzyıl (Çoruhlu, 2014:259).

$\mathrm{Bu}$ fresko detayında Garuda, pençelerinde bir insanla havada uçarken görüntülenmiştir. Garuda'nın yukarı doğru yükselişi ve insan figürünün dik duruşundan eylemin yeni gerçekleştiği hissini uyandırmaktadır. Yerden insanı kapan Garuda göğe doğru kanat açmış hızla yükselirken tasvir edilmiştir. Garuda bu fresko detayında da kartalı andıran bir görünüm sergilemektedir. Bu sade çizimde Garuda'nın kendine güveni ve sakinliği dikkat çekicidir. İnsan figürü erkeğe benzemekle beraber çok net olmasa da, yüz hatlarından ağzı açık bağırır bir tavır içinde görülmektedir. (Şekil:13). 
Efsanelerin, Garuda, Simurg, Anka vb. isimlerle anılan bu doğaüstü kuşun bir iyi birde kötü karakterli olduğundan daha önce bahsetmiştik. Bu Fresko çizimindeki Garuda'nın kötü karakterli ve insan yiyen Garuda olduğu hissi uyanmaktadır. Bu kanıyı bırakma sebebi, kuşun insanı tutuş biçimi diyebiliriz. Çünkü diğer Garuda, Simurg, Anka gibi kuşlar iyi karakterde iken, seyahat ettikleri insanları bu şekilde( pençeleri arasında) değil de, boyun veya sırt kısmında taşıdıkları efsane ve hikâyelerde yazılı olarak bahsedilirken, çizim ve minyatürlerde de görsel olarak betimlenmiştir (Şekil:13).

$\mathrm{Bu}$ duruma zit birkaç örneğin "Firdevs'inin, Şehnamesinde" bulunan Zal'ın Simurg tarafindan bulunup yuvaya götürülmesi ve yine Zal'ın babası Sam'ın Simurg'dan çocuğunu geri almak için geldiğini anlatan minyatürlerde bu tarz bir taşıma ( pençelerini kullanarak) görülmektedir. Ancak bu minyatürlerde "Firdevs'inin, Şehnamesinde" anlatılan Zal'ı besleyip büyüten Simurg iyi huylu ve merhametlidir. Bu anlatımı yapan minyatür örneklerinde ya Zal bebek yada küçük bir çocuktur. Simurg'un korunmasız bir çocuğu sırtına veya boynuna koyması mümkün olmadığından pençeleri arasında taşıdı $\breve{g} 1$ bir gerçek olsa gerek ki betimlemeler bu şekildedir.

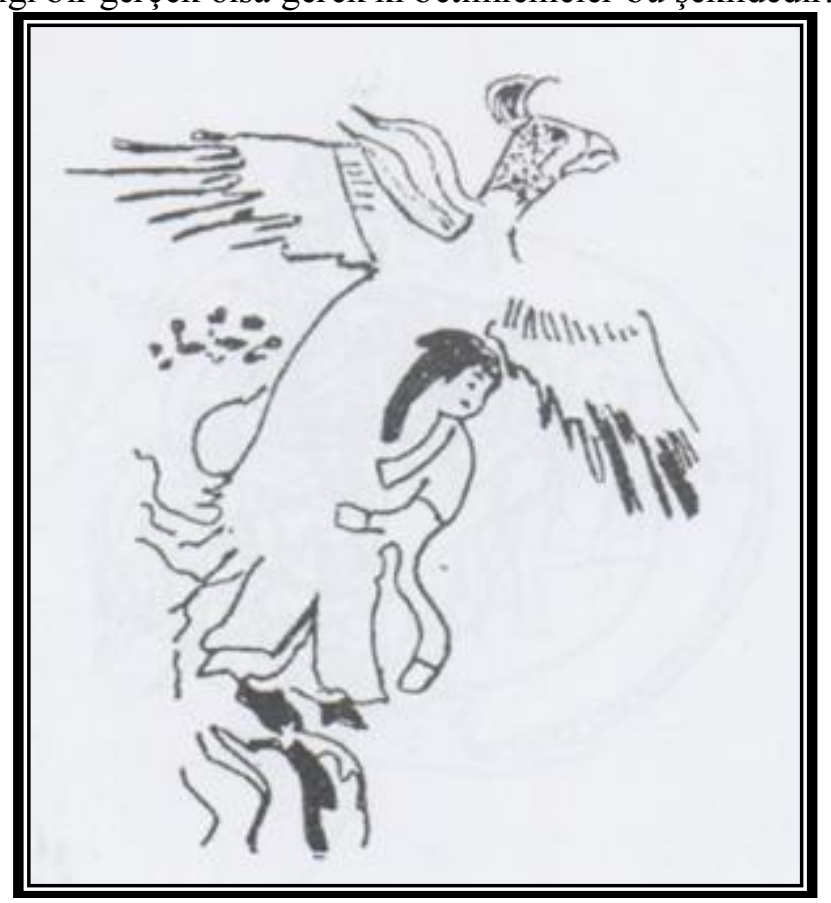

Şekil 14: Minyatür ( ayrıntı). Kadın Kaçıran Simurg. Herat 1408- 1506 ( Londra Royal Asiatic Societiy) (Çoruhlu, 2014:261).

$\mathrm{Bu}$ minyatür detayda (Şekil:14) Simurg'u kanatlarını açmış gökyüzünde yükselirken görmekteyiz. Kartal gagalı ve yine kartalı andıran başı ile kuş bakışı tepeden bir çizimle ele alınmıştır. Geniş kanatlarının altındaki gövdesi orantısız bir genişlikte çizilen Simurg'un kuyruğu da açık bir biçimde betimlenmiştir. Vücut ölçülerine oranla kısa çizilen kuyruğu ve rüzgâra zit çizilen ibiği oldukça dikkat çekicidir.

Kötü karakterli olduğunu düşündüğümüz Simurg’un bir kadını kaçırdığı görülmektedir. Kadın figürünün başı Simurg'a yapışmış, kollarıyla da sımsıkı sarılmış görüntüsünden ise, kadının yüksekten korktuğunu anlatması bakımından oldukça güçlü bir betimleme olmuştur. Kadının kafasını çevirip aşağı şaşkınlık ve hayret içinde bakması, yeryüzünü ilk defa kuş bakışı görmenin veya yaşadığı ortama belkide son kez bakmanın telaşını içermektedir(Şekil:14). 


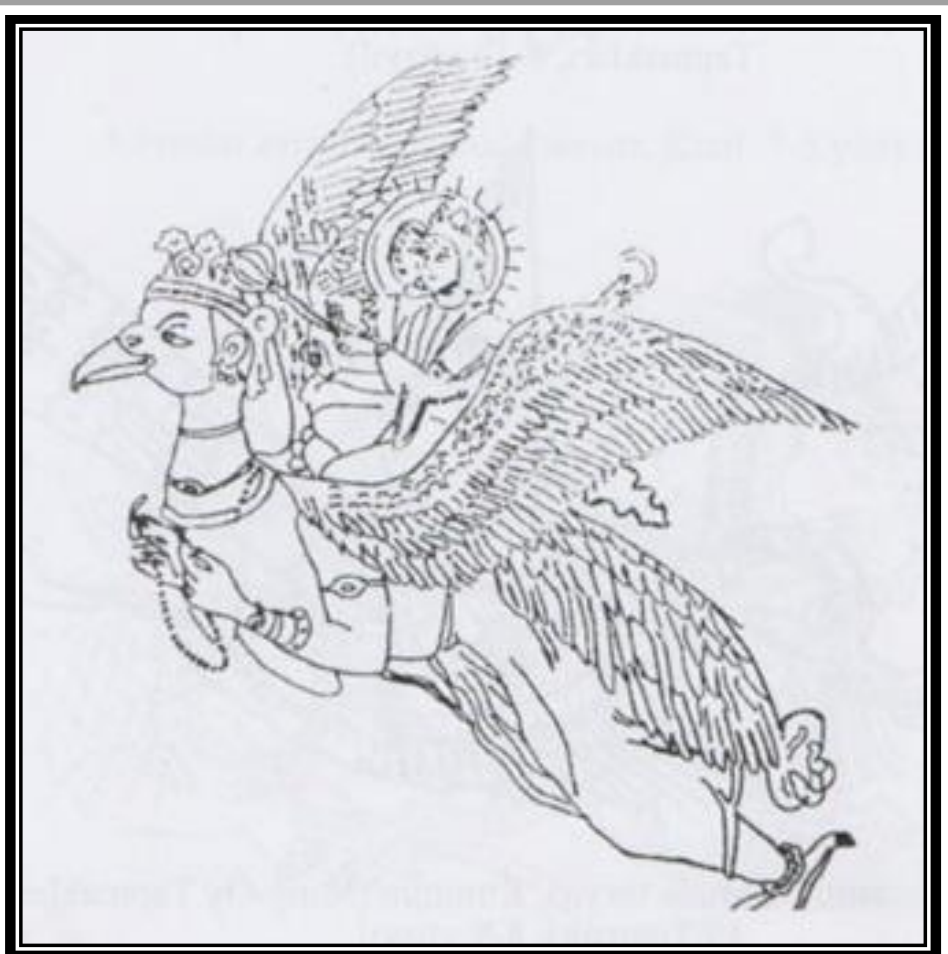

Şekil 15: Minyatür. Tanrı Vişnu Garuda üzerinde. Hindistan, XVIII. Yüzyıl (Çoruhlu, 2014:260).

$\mathrm{Bu}$ Minyatürde iyi karakterli Garuda sırtında, biri erkek diğeri kadın iki figürle havada uçarken görülmemektedir. Garuda'nın üzerindeki figür ÇORUHLU' nun kitabında, "tanrı Vişnu" olarak belirtilmiştir. Vişnu küt saçlı başında taç, sağ eli yukarı doğru açık, sol elinde ise ucu Garudanın başına uzanan bir taç ile betimlenmiştir. Tanrı Vişnu'nun ve yanındaki kadının başları daire biçiminde güneş motifini andıran bir hare içinde tasvir edilmiștir. İlahi dinlerde bu tarz harelerin kutsal kişiler, Peygamberler, peygamber soyundan gelen kişiler ve dört büyük meleğin tasvir edildiği minyatür ve resimler dede görülmektedir. Bu çizimde Tanrı Vişnu ve yanındaki kadının başındaki hare daha çok Hristiyanlarda kilise duvarlarına yapılan ikonalar ve yağlıboya resimlerde İsa Peygamberin başına çizilen ve kutsallık ifadesi taşıyan harelerle benzerlik göstermektedir. İslam resmi veya Osmanlı resim sanatı olarak bilinen minyatürlerde az sayıda görülen $\mathrm{Hz}$ peygamber çizimlerinin yanısıra, diğer peygamberler ve bazı meleklerin başlarında da kutsal kimliği ifade eden hareler kullanılmıştır. Fakat bu hareler alev biçiminde göğe doğru yükselir şekilde tasvir edilmiştir. $\mathrm{Bu}$ çizimdeki harenin Hıristiyan resim sanatındaki hareler ile benzerliği oldukça dikkat çekicidir(Şekil:15).

Garuda'nın elleri, kolları ve bacakları insan vücutlu tasvir edilirken, ayakları pençe, başı kuş biçiminde resmedilmiştir. Garuda'nın kanatları oldukça uzun ve geniş görkemli çizilirken kuyruk boyu bacakları aşmayacak biçimde bırakılmıştır. Garuda'nın iki elinde tespihi andıran bir ipe dizili boncuk görülmekte ve bu boncuğu sağ elinin işaret parmağı ile tespih çeker bir hava içeresindedir. Bununla birlikte, Garuda, başında geniş bantlı taşlarla süslü bir taç, boynunda, sol kolu ve bileğinde çeşitli takılar görülmektedir (Şekil:15). 


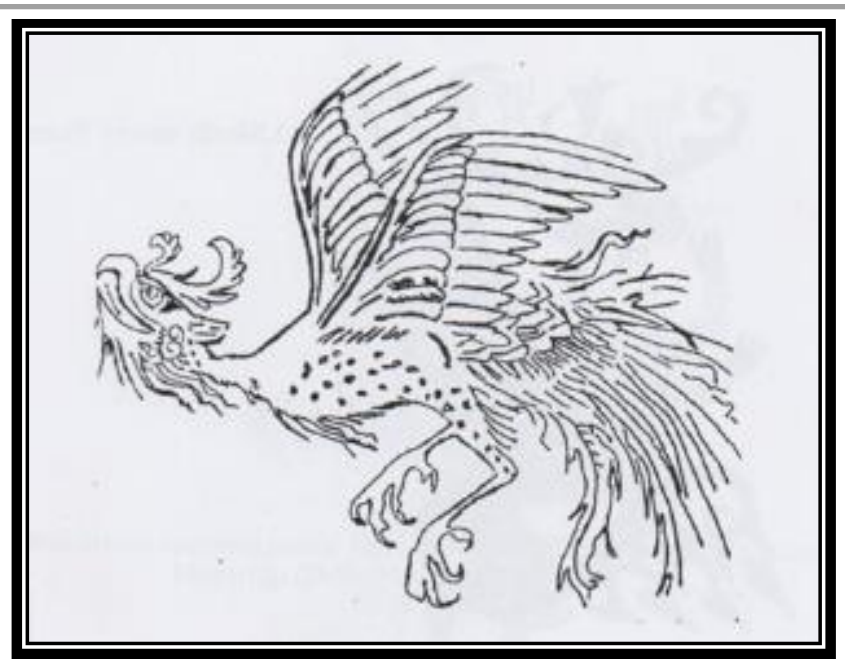

Şekil 16: Minyatür. Bordür Ayrıntısında Simurg Figürü. Hindistan XVII. Yüzyıl (Çoruhlu, 2014:261).

Minyatür bordürden alınan detay da Simurg'u, gökyüzünde bir yere konma hazırlığı içinde uçarken görmekteyiz. Bu hazırlığı pençe ve ayaklarını aşağı doğru indirmesinden rahatlıkla anlaya biliyoruz. Bir dala konmak veya avını kapmak için indirdiği pençeleri dört tırnaklıdır. Kartal gagalı ve başlı yorumlanan Simurg'un tepesi horoz misali ibikli, kısmen kuyruğu da horozun kuyruğunu andırmaktadır. Kartal kanatlı simurg, gözleri ileri doğru hedefine kitlenirken, gagası açık bir biçimde görülmektedir. Kitap sanatlarındaki pek çok Simurg ve Zümrüdü Anka betimlemelerinin bu tasarımdaki Simurg'la benzerliği oldukça önemlidir. Bu ve bunu andıran Simurg betimlemeleri, doğaüstü özelliklerden ziyade gerçekçi bir kuş çizimi ile güzellik kaygısından arınarak gücün simgesi olarak görülmesinden diyebiliriz (Şekil:16).
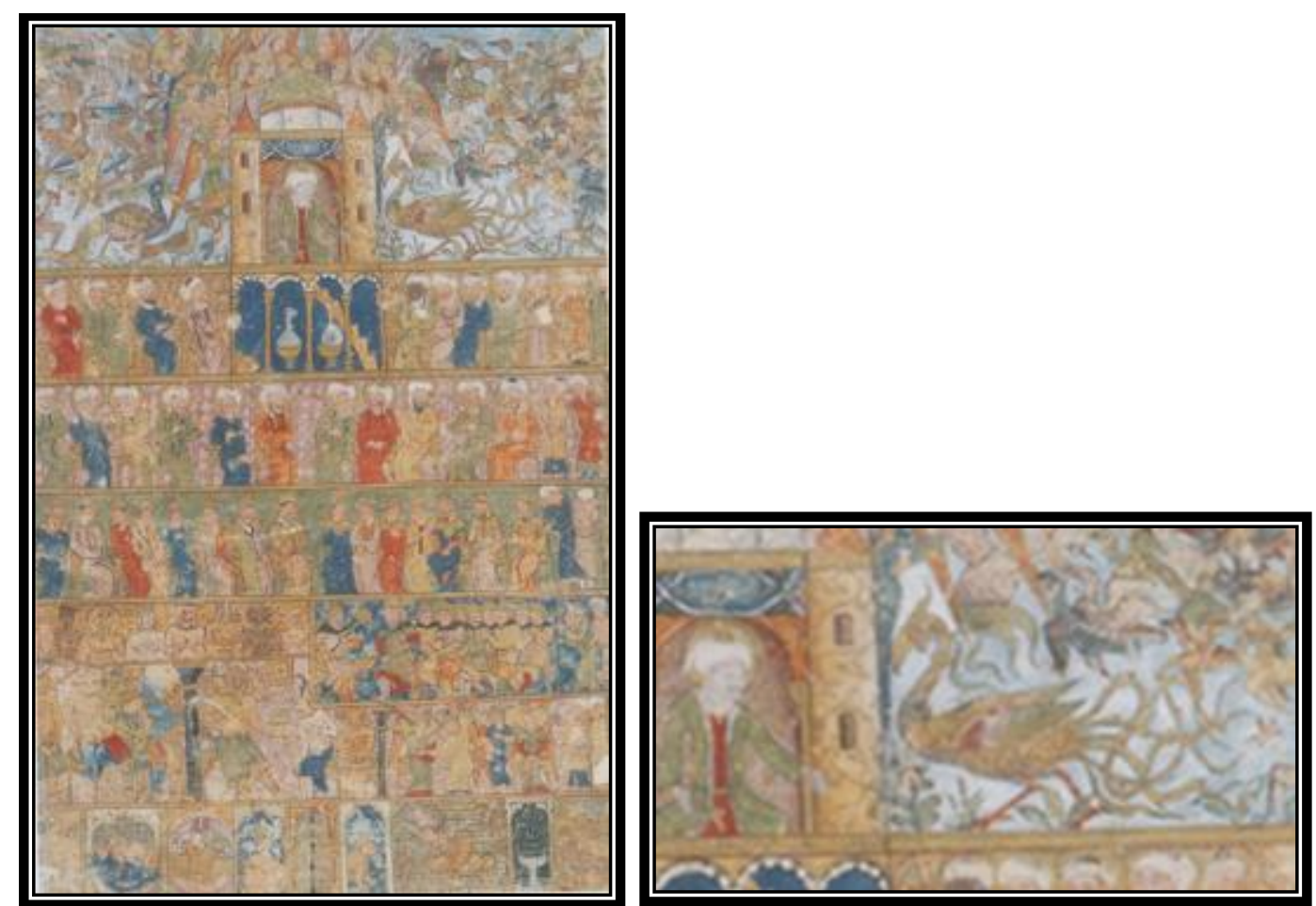

Şekil 17(a-b): Hz. Süleyman'ın sarayı ve çevresi ( cinler, yaratıklar, hayvanlar, askerler) Hz. Süleyman ( Süleymanname, CBL 406) (And, 2004:39). 
"Süleymanname" de bulunan Minyatür eser dikdörtgen planlı ve tam sayfadır. Sayfanın üst orta kısmında bir kubbeyi bağlayan iki kule arasında Hz. Süleyman başında sarık, üzerinde kırmızı gömlek üstüne yeşil kaftan, iki koluyla etrafindaki tebaasına hükmeder bir biçimde bağdaş kurmuş oturur pozisyonda tasvir edilmiştir. Hz. Süleyman'ın insanlar dışında melekler, cinler ve her türlü hayvanın dilini bildiği ve onlara Allahuteala'nın izniyle hükmettiği bilinir. Hz. Süleyman'ın sol kolu hizasındaki kulenin bitişiğinde Simurg- Zümrüdü Anka kuşu görülmektedir. Yüzü Hz. Süleyman’a dönmüş Simurg kartal gagalı, başı kepezli(başında uzun tüyler) uzun ve kalın bacaklı, ihtişamlı kuyruğuyla diğer kuşlardan hemen ayrılmaktadır. Yeşil, kırmızı ve altın yaldız (altın) kullanılarak renklendirilmiş Simurg iri cüssesi ile de ayrıca dikkat çekmektedir(Şekil:17a-b).

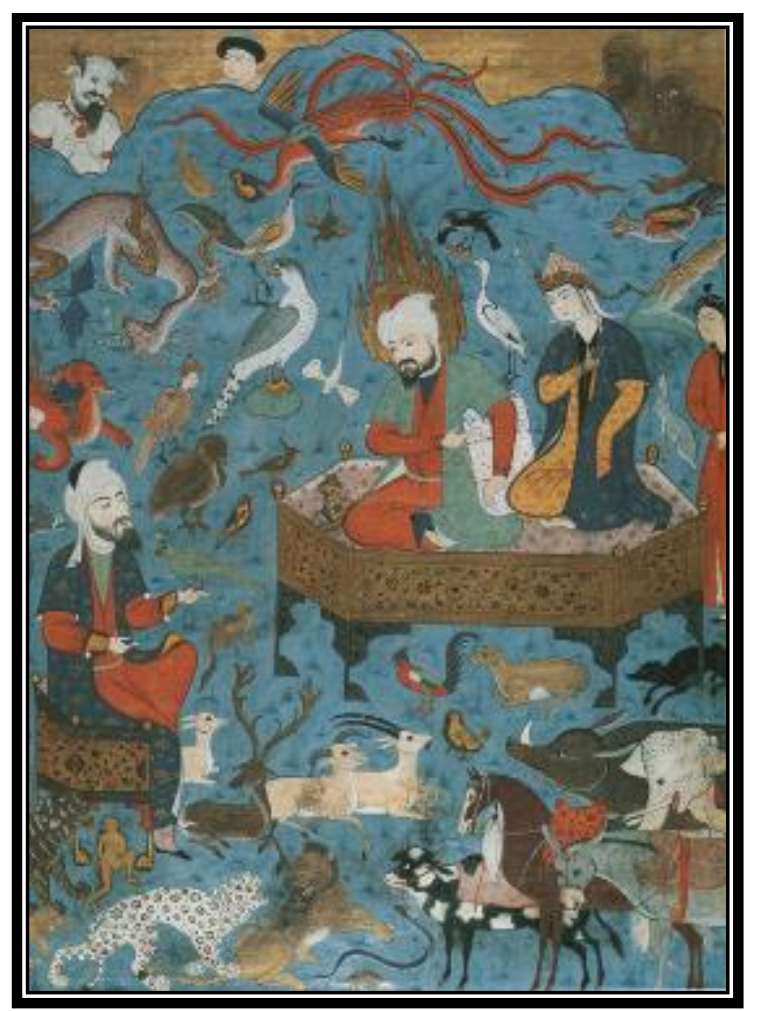

Şekil 18: Hz. Süleyman ve Seba Kraliçesi Belk1s. Falname.(TSM,H1703) (And, 2004:87).

Kalender Paşa tarafından hazırlanan Falnâme, I. Ahmed döneminin önemli eserlerinden biridir. Kendi türünde eşsiz bir kaynak olan bu eserin içinde toplam 35 minyatür bulunmaktadır. Minyatürlerinin çoğu dini ve mitolojik konularla ilgili ola Fal Name'nin içerdiği minyatürler, dönemin elyazmalarına oranla $48 \times 36 \mathrm{~cm}$. ölçüleriyle, minyatürlerin alışılmış boyutundan büyüktür (Onurel, 2014:115).

Falname adlı eserde bulunan minyatür tasarım da, dış mekân betimlemesi yapılmıştır. Minyatürde, Hz. Süleyman, Seba Kraliçesi Belkıs, vezir Âsaf, kanatlı bir melek, üç cin, bir hizmetkar görülmektedir. Simurg (Zümrüdü Anka), hüthüt, tavus, şahin, siren ( insan başlı kuş vücutlu, iyiliğin öncüsü yaratık) yanı sıra ejderha, at, domuz, aslan, maymun, tavşan, geyik, antilop, inek, eşek vb. pek çok evcil ve yabani hayvan bir arada girift bir görüntü içerisinde verilmiştir (Şekil:18).

Hz. Süleyman ve Belkıs, altıgen planlı geniş bir taht üzerinde, sağ elleri göğüslerinde, bağdaş kurmuş oturur vaziyette resmedilmiştir. Hz. Süleyman ve Belkıs'ın oturuş biçimi Türk oturuşu diye bilinen bağdaş kurma biçiminde tasvir edilirken, Hz. Süleyman'ın hemen karşısında küçük bir tahta oturan vezir Âsaf, sol dizini yukarı çekmiş rahat bir tavır içinde görülmektedir. Âsafın 
sağ eline konmuş bir kuş ve sol elinin baş ve işaret parmağıyla Hz. Süleyman a söz söylerken betimlenmiştir. Hz. Süleyman, Belkıs ve Âsaf'ın kıyafetleri yaşadıkları dönemden çok resmedildikleri dönemin tarzı geleneksel Osmanlı kıyafetleri içinde, içlik üzerine uzun eteklik ve kaftanla betimlenmişlerdir. Hz. Süleyman ve Âsaf'ın başlarında Osmanlı sarığı görülürken Süleyman'ın sarığı kutsallığı simgeleyen alevli harelerle çevrilidir. Melek figürü Belkıs'ın sol tarafında, tahtın hemen arkasında ayakta durur bir hareket planında çizilmiştir. Tasarımın betimlendiği mavi zeminli tepenin arkasında, sağ köşede boynuzlu ve sakallı bir cin, sol köşede siyah renkli iki cin ve ortada bir Âdemoğlu betimlenmiştir(Şekil:18)

Bu minyatür tasarımda konumuz olan Simurg tahtta oturan Hz. Süleyman'ın başının hemen üzerinde uçar bir vaziyette resmedilmiştir. Diğer Simurg betimlemeleriyle karşılaştırıldığında oldukça benzer özellikler gösterse de, kanat boyunun kısalığı ve vücut boyunun uzunluğu dikkat çekicidir. Beş parçalı kuyruk uzunluğu ve görüntüsü alışılmış bir yorum olmakla beraber oldukça yalın bir betimleme sergilemektedir. Kırmızı rengin boyun, gövde ve kuyruk kısmında hâkim olduğu Simurg'un kanat ve baş kısımlarında mavi, altın yaldız (altın) ve yeşil renkler ile renklendirilmiştir.

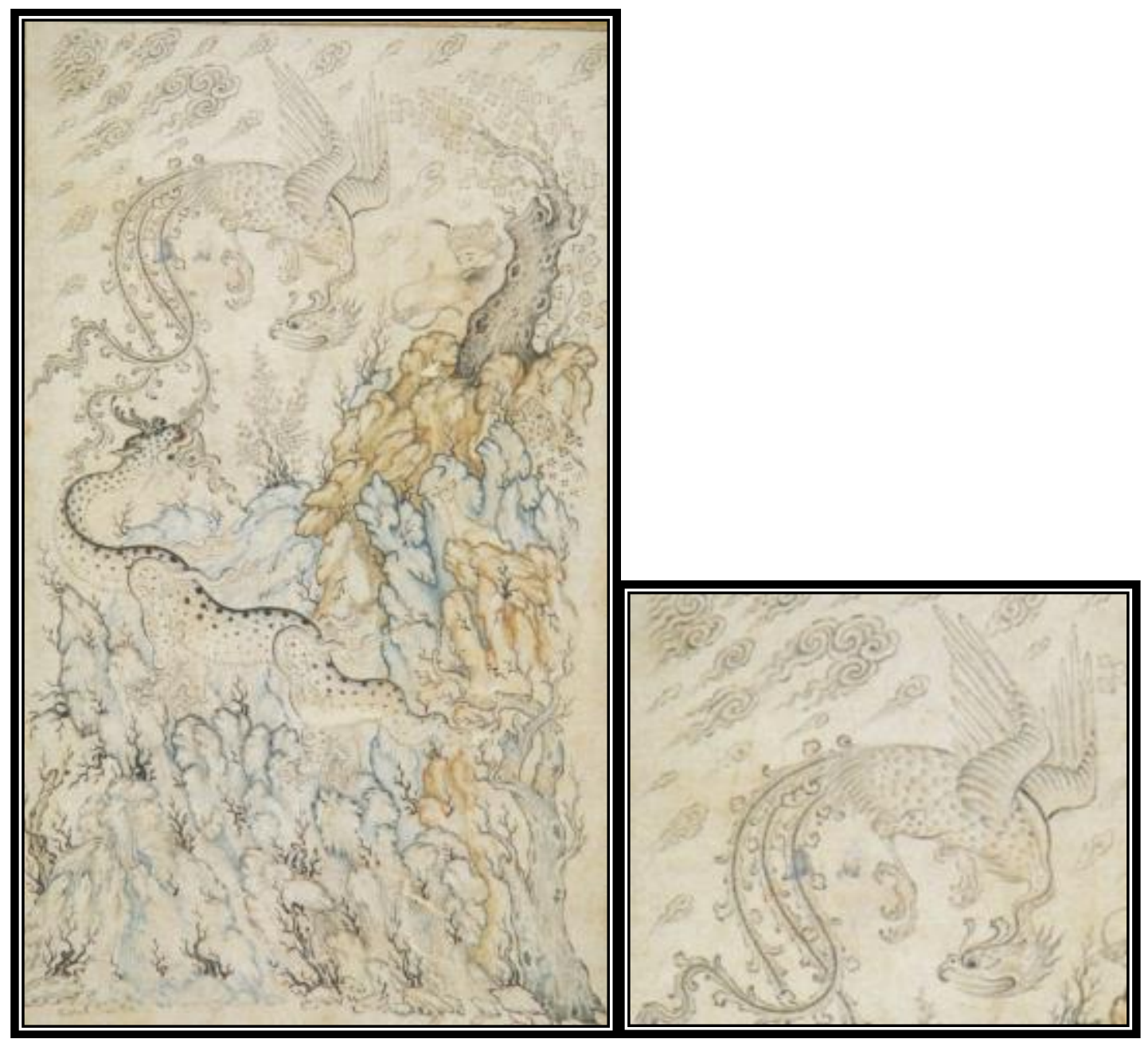

Şekil 19(a-b): Simurgla Ejderhanın Savaşı. Saz Üslubunda.(TSM,H2163) (And, 2004:57).

Saz üslübun'da yapılan dikdörtgen planlı eserde, Simurg ve bir ejderha savaş halinde resmedilmiştir. Kayalıklar üzerindeki dört ayaklı dev ejderha, Simurg'un kuyruğunun bir kısmını ağzına almış bir pozisyonda çizilmiştir. Kuyruğundan yakalanan Simurg, can havliyle ejderhaya 
doğru bir dönüş hareket planında çizilmiştir. Simurg çizimi, dönüş anındaki vücut hareketi ile kıvrak ve esnekliğini göstermesi açısından oldukça iyi bir örnek oluşturmaktadır. Ağzı açık saldırıya hazırlanan Simurg çizimi, diğer örneklerle benzerliği dikkat çekerken, kuyruk kısmındaki tüylerin saz yaprağını andıran yorumu göz doldurmaktadır. (Şekil:19a-b)

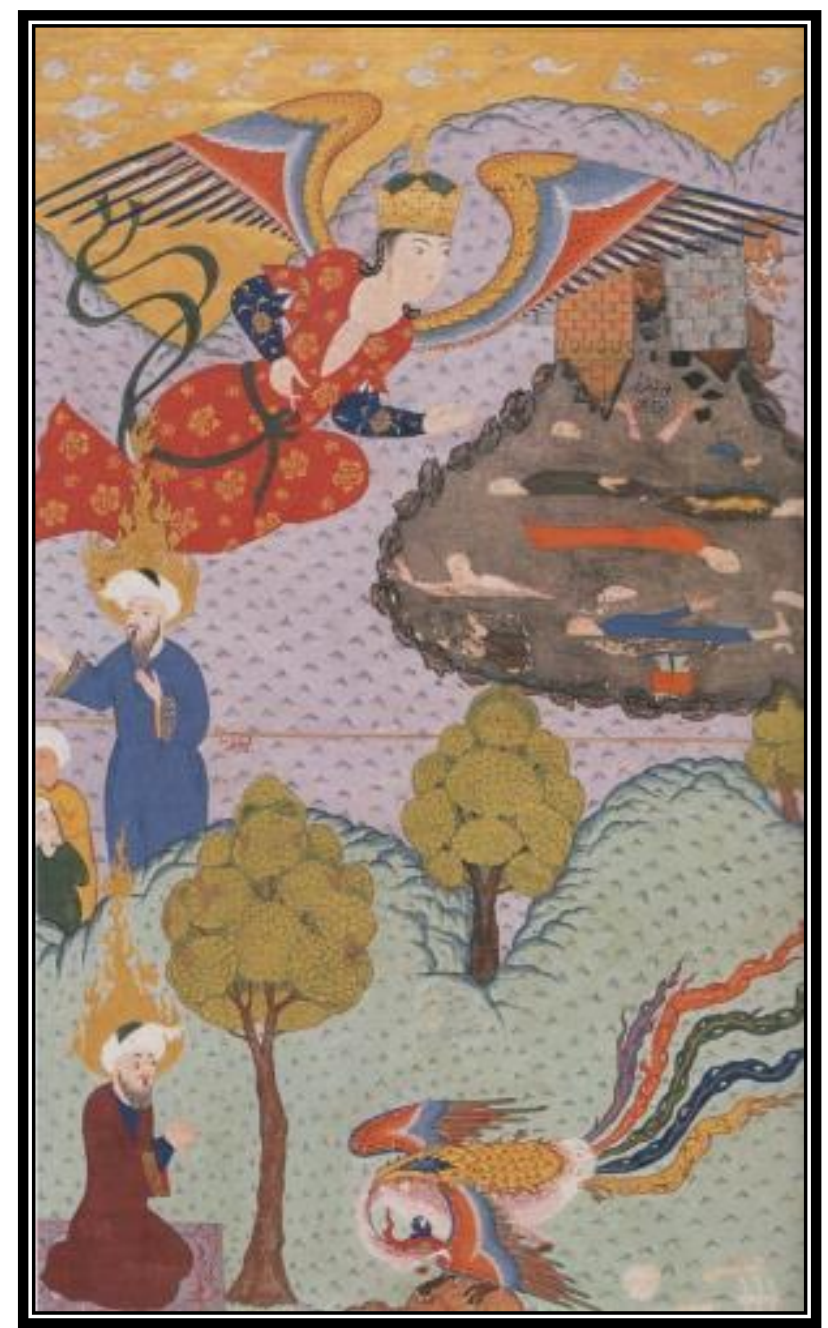

Şekil 20: Sodom Yıkılırken Hz. Lut Seyrediyor ( üstte), Hz. Hanzale Bin Saffan ve Simurg.

Zübdetü’t- Tevarih. ( TIEM, 1973) (And, 2004:302).

Zübdetü’t- Tevarih adlı eserde bulunan minyatürde (şekil:20), iki konu ele almıştır. Sayfanın üst kısımda Hz. Lut'un kötü huylu kavmine söz geçiremeyince, Allahuteala'dan yardım isteği üzerine Cebrail'in Sodom şehrini yıkması betimlenmiştir. Kompozisyonun üst kısmında kanatları sağ ve sol köşelere dayanan Cebrail Sodom'u yıkarken tasvir edilmiştir. Sodom halkı havuzu andıran bir alan içerisinde balçık ve çamur içinde boğulurken tasvir edilmiştir. Cebrail' in sol kanadı altındaki Sodom şehrinin ters dönmüş evleri, yerle bir olan şehri temsilen çizilmiştir. Yerle bir olan Sodom şehrinin sağ köşesinde Hz. Lut ve iki evladı arkası dönük ( Allahın emri üzerine, arkalarına bakmadan) mekândan uzaklaşırken görülmektedir.

Minyatür tasarımın alt kısmında, Hz. Hanzale bin Saffan ve Simurg betimlenmiştir. Simurg'un insanlara saldırıp, insan yemeye başlaması üzerine halk Hz. Hanzale bin Saffan'dan yardım ister. Hz. Hanzale'de Allahuteala'dan yardım ister ve Simurg ölümle cezalandırılır. Sağ alt köşede bir ağaç altında, diz çöküp oturmuş ve ellerini semaya açmış dua eden Hz. Hanzale 
görülmektedir. Sol alt köşede Simurg ve yediği insanları temsilen insan kemikleri resmedilmiştir. Simurg bir kayanın üzerine tünemiş insan kemiklerine bakarken betimlenmiştir. Kompozisyona sığmayan gösterişli kuyruğunda kullanılan, mor, kırmızı, yeşil, mavi ve sarı renkler tüm vücudunda dengeli bir biçimde dağıtılırken, karın ve boyun kısmında pembe renge yer verilmiştir. Diğer Simurg betimlemeleri ile oldukça benzer özellikler taşıyan kartal gagalı kuş'un sırt kısmında saz yaprağını andıran tüyler görünürken, küçük bir ibik ve kepezle kuş yorumu tamamlanmıştır. (Şekil:20)

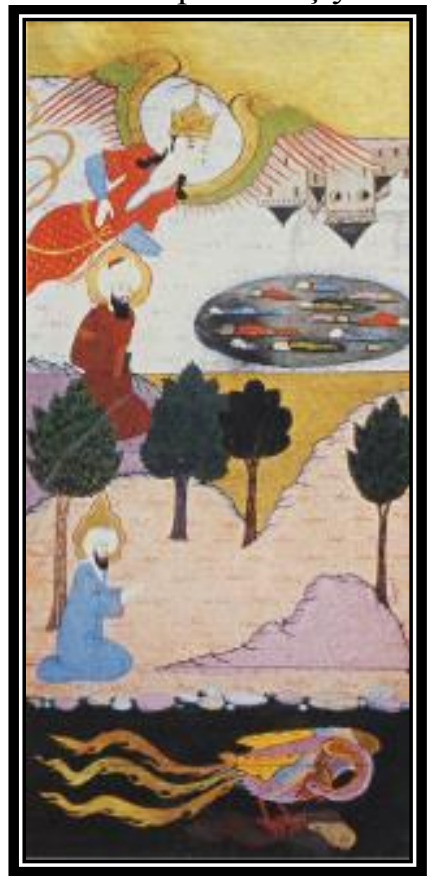

Şekil 21: Hz. Lut Sodom'un Yıkılışını Seyrediyor. Alt kesimde Hz. Hanzale Bin Saffan ve Simurg. Zübdetü'tTevarih. ( TSM H.1321) (And, 1998:209).

Yine Zübdetü't- Tevarih adlı eserde bulunan bu minyatürde de aynı iki konu, benzer bir biçimde işlenmiştir. İki minyatür arasındaki farklardan biri, Hz. Lut'un Sodom Şehri'nin Cebrail tarafindan yıkılırken izliyor olmasıdır.

Minyatür tasarımın alt köşesinde yine, Hz. Hanzale bin Saffan ve Simurg betimlemesine yer verilmiştir. Sağ alt köşede bir ağaç altında dizleri üzerine oturmuş, ellerini semaya açmıs dua eden Hz. Hanzale görülmektedir. Alt bölümde ise, Simurg ve Simurg'un pençeleri altında yakalayıp öldürdüğü bir genç görülmektedir. Simurg'un başı horoz başını anımsatırken, uzun boynu, kanat ve kuyruğu diğer yorumlarla benzer özellikler sergilemektedir. Altın yaldız ( Altın), kullanılan kuyruk ve kanat uçları dışında, Simurg mavi, gri ve pembe renklerle renklendirilmiştir(Şekil:21). 


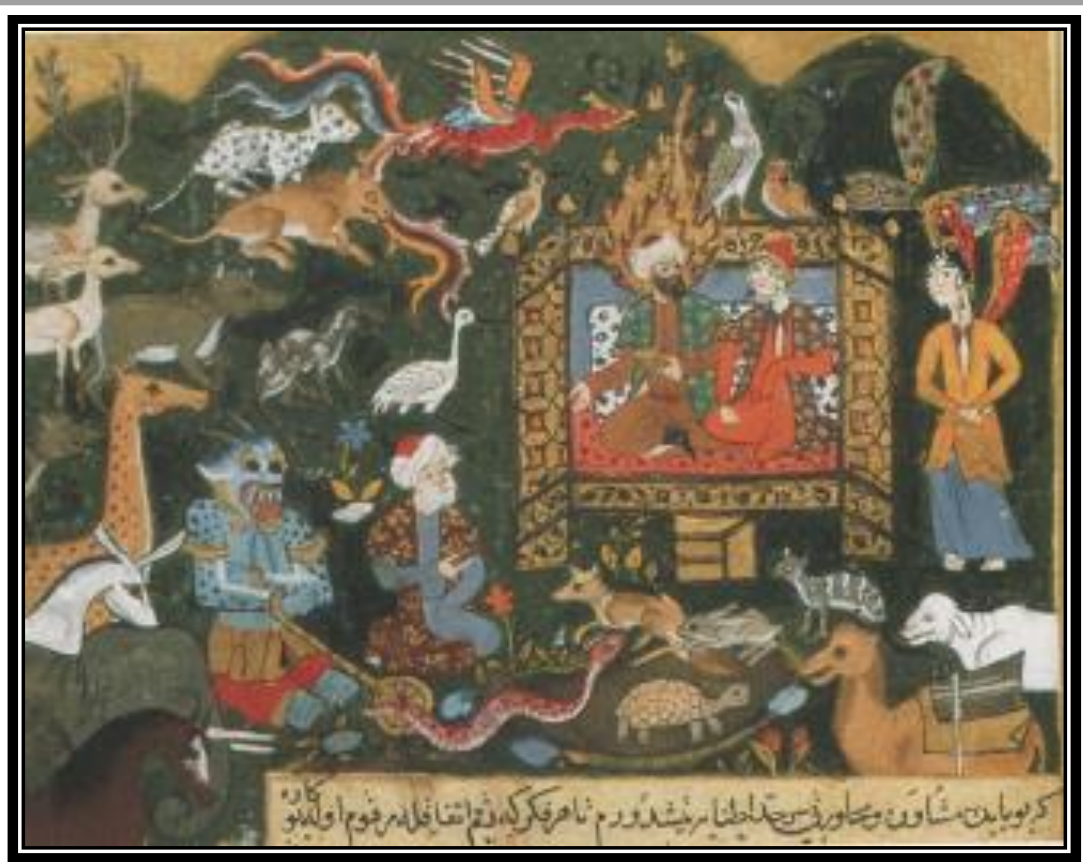

Şekil 22: Hayvanlar ve Yaratıklarla Çevrili Hz. Süleyman'a Yaşam Suyunun Getirilmesi. Humayunname.(BL, Add. 15153) (And, 2004:84).

Hümayûnnâme' de bulunan bu minyatür (şekil:22) tasarımda Hz. Süleyman ve Belkıs üç tarafı çevrili, üç basamaklı bir taht üzerinde bağdaş kurmuş oturur vaziyette betimlenmiştir. Süleyman, Belkıs ve vezir Âsaf'ın üstünde, eteklik üzerine yarım kollu kaftan görülmektedir. Hz. Süleyman ve Âsaf'ın başlarında sarık, Belkıs'ın başında altın taç ile betimlenirken, Süleyman'ın başında kutsallık ifade eden alevli hare görülmektedir.

Tahtın karşısında, çimler üzerinde dizüstü oturmuş vezir Âsaf, Âsaf'ın arkasında yine dizüstü oturmuş kolları birbirine kenetlenmiş boynuzlu bir cin ve Belkıs'ın solunda tahtın yanında ayakta duran kanatlı bir melek tasvir edilmiştir. Birbirlerini izler bir hareket planında çizilen $\mathrm{Hz}$. Süleyman ve Belkıs hafif bir tebessüm halinde görülürken, Süleyman'ın sol elinde içinde abı- hayat suyu olan, altın bir tas gözükmektedir.

Taht üzerine konan sağdan sola sırayla hüthüt, şahin, baykuş ve tavus kuşları bu mutluluğun en yakın şahitleri gibi görülürken, tahtın etrafında Simurg, leylek, köpek, kaplan, geyik, zürafa, domuz, at, eşek, fil, yılan, deve, tavşan, kaplumbağa vb. evcil ve yabani hayvanlar tasvir edilmiştir.

Simurg minyatür tasarımın üst bölümünde, Hz. Süleyman'ın tahtı üzerinden uçar bir pozisyonda resmedilmiştir. Bu kompozisyonda Simurg'un kafası bir horozu andırırken, kanatlarının oldukça küçük çizildiği görülmektedir. Kuyruk kısmının uzunluğu vücudun iki buçuk katı kadar olması diğer Simurg betimleriyle benzerlik gösterirken, boyun kısmının aşırı uzunluğu dikkat çekicidir. Uçan Simurg'un havadaki uzun kuyruğunun bir kısmı yerde uzanmakta olan kaplanın başının arkasında kalması kısmen bir çizim hatasını gösterirken, muhtemelen kaplanın kafasının kapatılmaması amaçlanmıştır diyebiliriz. Beyaz tahrirlenen Simurg'un kuyruğu turuncu, mavi, kahve ve pembe renklerle renklendirilirken, kanatlarında turuncu, gövdesinde kırmızı ve mavi renkler kullanılmış oldukça yalın bir betimleme olarak karşımıza çıkmaktadır(Şekil:22). 


\section{Zümrüdü Anka ( Kara Kuş) Yorumu}

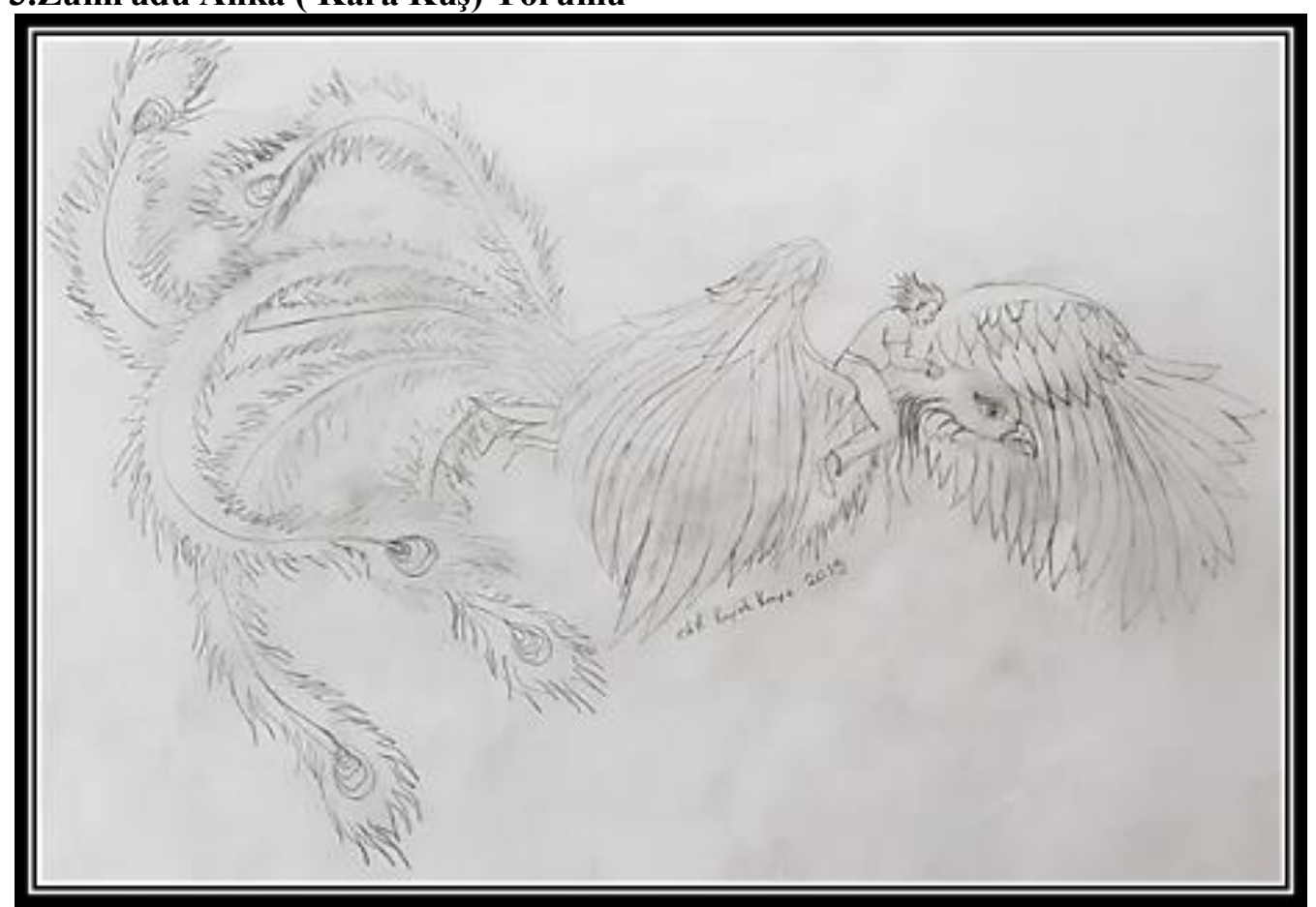

Şekil 23: Minyatür. Zümrüdü Anka (Simurg, Karakuş)’nın Sırtında Yolculuk Yapan Ertöştürk.

Tasarım Ertöştürk destanında bahsi gecen, Karakuşun üzerinde yolculuk yapan Ertöştürk ve Karakuş resmedilmiştir. Minyatür tasarım $35 \times 50$ boyutlarında, enine bir planda çizilmiştir. Havada uçar bir pozisyonda görülen Karakuş'un baş çizimi için kaz ve kuğudan ilham alınırken, gagası Simurg ve Anka tanımlamaları ve yine minyatür yorumlarında sıklıkla karşılaştığımız kartal gagası olarak çizilmiştir. Kanatları kartal ve ak baba kuşlarından ilham alınan Karakuş (Zümrüdü Anka)'un kuyruk tasarımı tavus ve Simurg - Anka yorumlarından esinlenilmiştir. Kuşun boyun ve gerdan kısmından aşağı sarkan tüyler ile Karakuş (Zümrüdü Anka)'a zenginlik katılmak istenmiştir.

Anka'nın boynunda Ertöştürk figürü görülmektedir. Ertöştürk elleriyle kuşun tüylerinden sıkı sıkı tutarken, ayaklarıyla da kuşu sarmış bir pozisyonda resmedilmiştir. Ertöştürk'ün saçlarının arkaya doğru savrulmasından Karakuş (Zümrüdü Anka)'un hızını anlamak mümkündür. Tasarımda Karakuş'un vücut kısmının kısa, kuyruk kısmınınsa bir oka dar uzun olması kuşa farklı bir yorum kazandırmıştır diyebiliriz. 


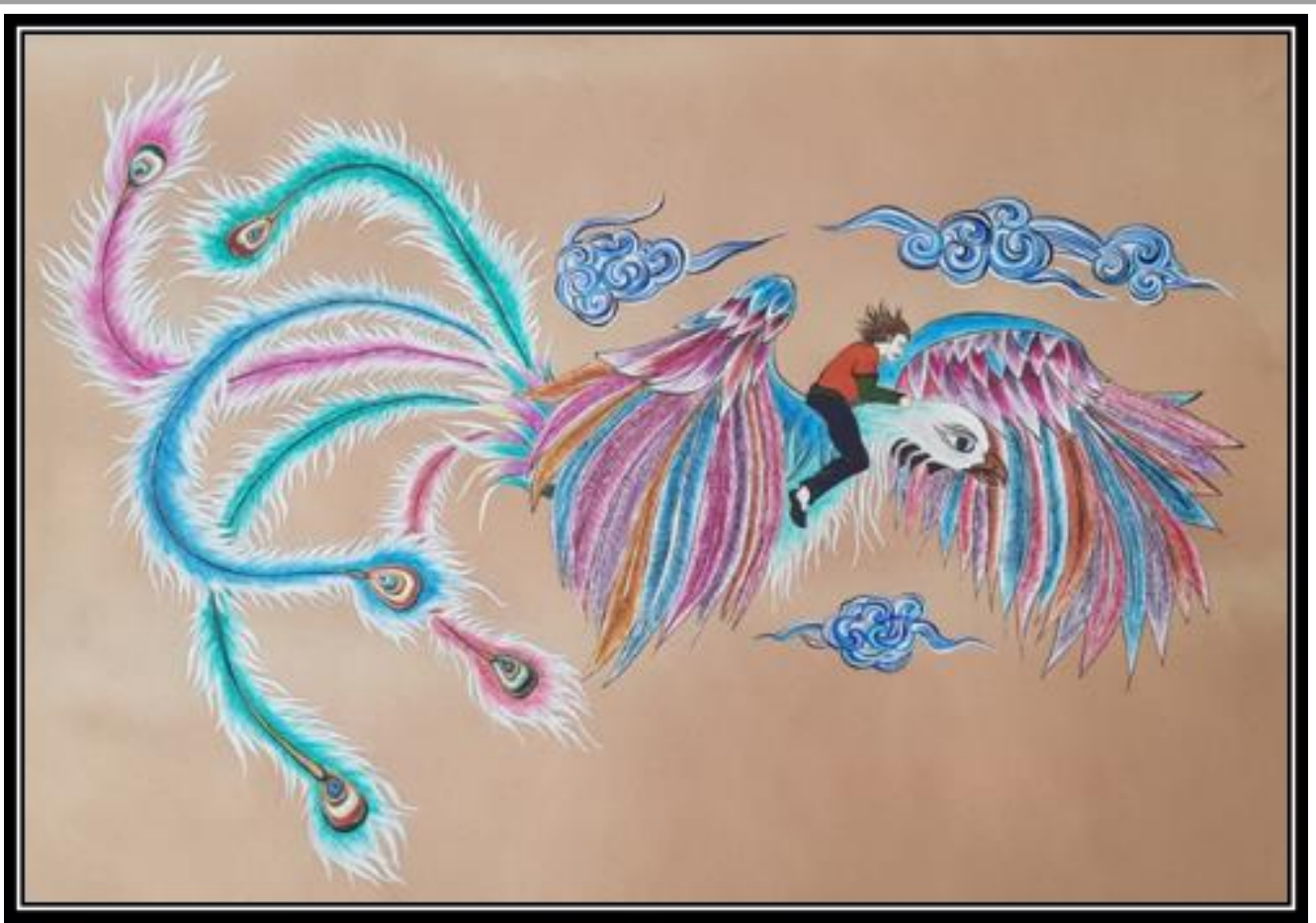

Şekil 24: Minyatür. Simurg’un Sırtında Yolculuk Yapan Ertöştürk (B. Kaya, 2019).

Karakuş (Zümrüdü Anka)'un kuyruğunda ağırlıklı olarak mavi, pembe ve yeşil renk kullanılırken, kuyruk ucundaki halkalarda; altın, siyah, beyaz, kırmızı, mor, mavi ve turuncu renkler ile renklendirilmiştir. Karakuşun kuyruğunda kullanılan renkler, orantılı bir biçimde tüm vücuda dağıtılmıştır. Ceviz rengine boyanan tasarımın çizildiği kâğıt doğal rengiyle bırakılırken, kuşun etrafına gökyüzü imgesi oluşturmak için münhani tekniğiyle yapılmış üç serbest bulut çizimi yapılmıştır.

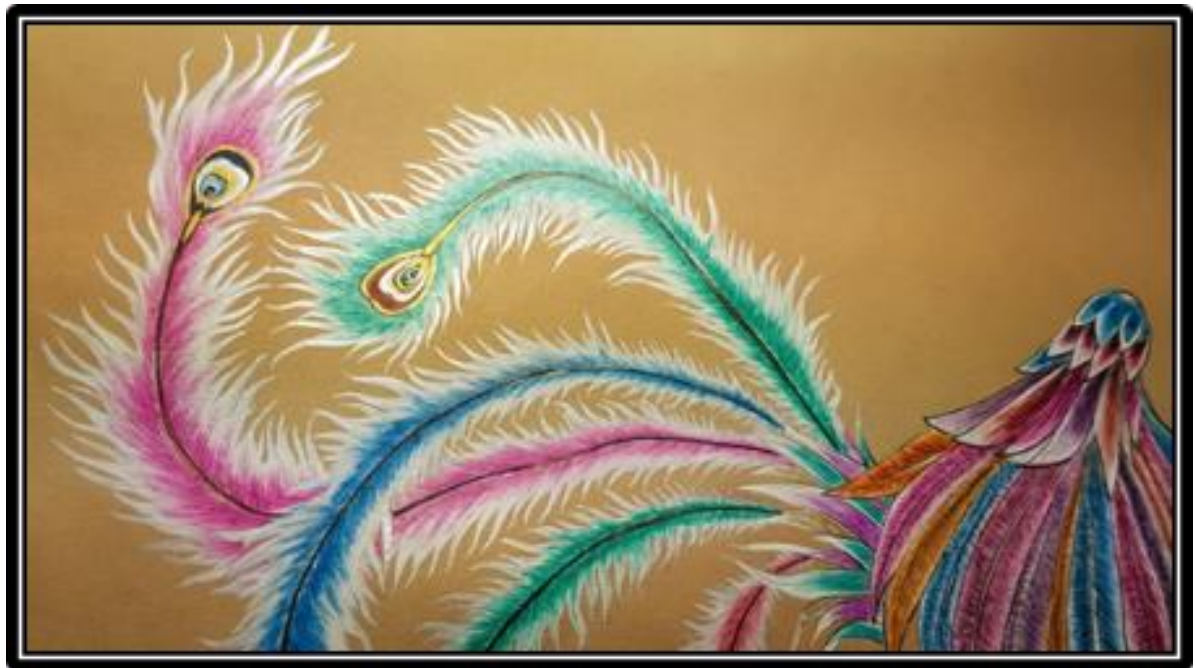

Şekil 25: Şekil (24) Minyatür den Bir Detay (B. Kaya, 2019).

Turkish Studies - Social Sciences

Volume 14 Issue 6, 2019 


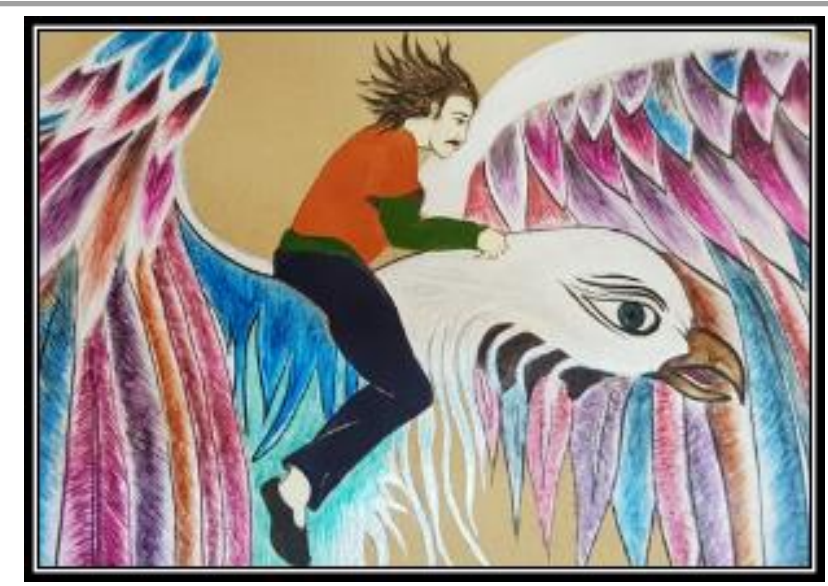

Şekil 26: Şekil (24) Minyatür den Bir Detay (B. Kaya, 2019).

\section{Sonuç}

Simurg doğadaki pek çok kuşun farkl1 özelliklerini, kabiliyet ve görünüm olarak bünyesinde toplamaktadır. Bu özelliğiyle de Türk İslam sanatının temel prensiplerinden olan doğada var olanı birebir almak yerine, kendi cinsi içerisindeki pek çok unsurun birleşimi ile ortaya çıkan yeni bir tür oluşturma çabasını Simurg veya Zümrüdü Anka yorumlarında açıkça görmekteyiz. Tam stilize veya yarı stilize dediğimiz bu farklılaştırma veya yeni bir tür ortaya koyma çabası tamamen yaratanın, yaratmış olduklarını birebir kopya etmekten itina ile uzak durma çabasıdır ki bu bizi dünyada eşi olmayan Türk İslam sanatlarının doğuşunun başlangıcıdır desek ileri gitmiş sayılmayız. Doğaüstü bir karakter olan Simurg'un üstün meziyetlerinin yanında pek çok kuşun birleşiminden oluşan fiziksel görünümü, bir birinden farklı yorumlar ortaya çıkmasına sebep olurken, Simurg karakterine hayat veren sanatkârların inanç başta olmak üzere, içinde yaşadıkları toplumun kültürel değerleriy ile yorumlamış olmaları da son derece mühimdir.

Zümrüdü Anka/Sîmurg, Garuda, Tugrul, Kara-kuş, Grifon, Saena, , Phoenix gibi isimlerle anılan doğaüstü güçlere sahip, bu muhteşem kuş bazı efsanelerde iyilik ve şifa saçan bir koruyucu, bazı efsanelerde ise dehşet ve ölüm saçan bir canavar olarak karşımıza çıkmaktadır. Efsanelerin yazılı olduğu metinler arasında, konuyu açıklayıcı resimler olarak yapılan minyatürler ise bize, efsanenin anlatıldığı dönemde, Simurg'un halkın ve sanatçının gözüyle görmemize olanak sağlayan çok kıymetli veriler olmuştur. Yazılı metinlerde bahsedilen Simurg betimlemeleri hayal denizinde yelken açmamıza olanak tanırken, minyatür tasarımlar halinde, çizgileri esir alıp renklere bulanan, Simurg izleyicisinde hayret ve hayranlık uyandıran, görsel bir şölen oluşturmuştur. Konumuz olan Simug'u ve icraatlarını konu alan kıymetli minyatür eserlerin bir kısmını incelenerek (derlenerek), yeni bir Simurg ( Karakuş) yorumu beğeni ve değerlendirmeye sunulmuştur.

\section{KAYNAKÇA}

And, M. (1998). Minyatürlerde Osmanl1-İslam Mitologyası. İstanbul: Yapı Kredi Yayınları.

And, M. (2004). Osmanlı Tasvir Sanatları 1. İstanbul: İş Bankası Kültür Yayınları

Ateş, F. (2017). Saim Sakoğlu'nun "Kıbrıs Masalları" adlı kitabında yer alan mitolojik unsurlar. Avrasya Uluslararası Araştırmalar Dergisi, 5(11), 217.

Bayrak, C. Kişisel iletişim ( 25 Mart 2016) 
Çoruhlu, Y. (2011). Türk mitolojisinin ana hatları. İstanbul: Kabalcı Yayınları

Çoruhlu, Y. (2014). Türk Sanatında Hayvan Sembolizmi. Ankara: Kömen Yayınları

Firdevsi (2017). Şehname I (çevirmen:Prof.Necati Lugal). İstanbul: Kabalcı Yayıncılık.

İnal. G.(1995).Osmanlı Kitap Resminde Süleyman Peygamber İkonografisi. Atatürk Kültür, Dil Tarih Yüksek Kurumu Atatürk Kültür Merkezi Yayınları, Ankara

Oener, L. (2018). Sâbit dîvânı'nda mitolojik ve efsânevî kuşlar. Türk Uluslararası Dil Edebiyat ve Halkbilimi Araştırmaları Dergisi, 6(13), 321.

Onurel, R. (2014). Osmanlı kitap resminde Süleyman peygamber ikonografisi. İstanbul: Ege Yayınları

Ögel, B. (2014). Türk Mitolojisi (Cilt 2). Ankara: Türk Tarih Kurumu

S. Alsan, Ş. (2017). Türk Mimari Süsleme Sanatında İkonografik Figürler, Ankara

T. Apak, F. (2015). "Elma Ağacı" masalı üzerinde mitolojik bir çözümleme denemesi. Studies Of The Ottoman Domain, 5(9), 60. 